NBER WORKING PAPER SERIES

\title{
BIRTHS, DEATHS, AND NEW DEAL RELIEF DURING THE GREAT DEPRESSION
}

\author{
Price V. Fishback \\ Michael R. Haines \\ Shawn Kantor \\ Working Paper 11246 \\ http://www.nber.org/papers/w11246 \\ NATIONAL BUREAU OF ECONOMIC RESEARCH \\ 1050 Massachusetts Avenue \\ Cambridge, MA 02138 \\ March 2005
}

The views expressed herein are those of the author(s) and do not necessarily reflect the views of the National Bureau of Economic Research.

(C2005 by Price V. Fishback, Michael R. Haines, and Shawn Kantor. All rights reserved. Short sections of text, not to exceed two paragraphs, may be quoted without explicit permission provided that full credit, including (C) notice, is given to the source. 
Births, Deaths, and New Deal Relief during the Great Depression

Price V. Fishback, Michael R. Haines, and Shawn Kantor

NBER Working Paper No. 11246

March 2005

JEL No. I38, J11, N32

\begin{abstract}
This paper examines the impact of New Deal relief programs on infant mortality, noninfant mortality and general fertility rates in major U.S. cities between 1929 and 1940. We estimate the effects using a variety of specifications and techniques for a panel of 114 cities for which data on relief spending during the 1930s were available. The significant rise in relief spending during the New Deal contributed to reductions in infant mortality, suicide rates, and some other causes of death, while contributing to increases in the general fertility rate. Estimates of the relationship between economic activity and death rates suggest that many types of death rates were pro-cyclical, similar to Ruhm's (2000) findings for the modern U.S.. Estimates of the relief costs associated with saving a life (adjusted for inflation) are similar to estimates found in studies of modern social insurance programs.
\end{abstract}

Price V. Fishback

Department of Economics

University of Arizona

Tucson, AZ 85721

and NBER

pfishback@eller.arizona.edu

Michael R. Haines

Department of Economics, 217 Persson Hall

Colgate University

13 Oak Drive

Hamilton, NY 13346

and NBER

mhaines@mail.colgate.edu

Shawn Kantor

School of Social Sciences, Humanities and Arts

University of California, Merced

P.O. Box 2039

Merced, CA 95344

and NBER

skantor@ucmerced.edu 


\section{Births, Deaths, and New Deal Relief during the Great Depression}

\section{Introduction}

How well do social welfare programs mitigate the effect of economic disasters on demographic outcomes? To answer this question, we examine the effect of New Deal relief programs on fertility, infant deaths, noninfant deaths, suicides, homicides, and other causes of death during the Great Depression. During the 1930s Americans experienced an economic disaster that lasted an entire decade. Unemployment rates peaked at well over 20 percent of the labor force and real GNP fell by roughly onethird between 1929 and 1933. Real GNP did not reach its 1929 level again until the end of the decade and the unemployment rate remained over 10 percent throughout the decade. The numbers do not reveal the full devastation experienced during the 1930s, as many people stood in bread lines, lost their homes, their jobs, and their hope for the future. Such a dramatic economic shock was likely to contribute to substantial shifts in demographic outcomes. The sharp reductions in income and consequent inadequate access to nutrition, housing and medical care put infants and people of all ages at greater risk of death and disease. Economic problems potentially fueled psychological depression that contributed to more suicides and social and economic stresses that led to more homicides. Meanwhile, the greater uncertainty about the future led many families to delay child-bearing.

To combat the Depression, the federal government expanded its social welfare spending in a dramatic and unprecedented fashion. As the economy slid toward the trough of the Depression in the early 1930s, the burden of providing relief rested on state and local governments and private charitable organizations. As the lower levels of government were overwhelmed by the scope of the problem, the Hoover administration provided loans through the Reconstruction Finance Corporation so that state and local governments could fund relief in the latter part of 1932. Per capita relief spending rose from $\$ 3.90$ in 1930 to $\$ 18.70$ in 1932 (constant 1967 dollars). It was Roosevelt's New Deal, however, that

revolutionized welfare spending both in the short term and the long term. The federal government poured resources (sometimes in partnership with state and local governments) into the provision of emergency 
work relief and direct relief during the First New Deal (1933-1935). After 1935 through the beginning of World War II, the federal government continued providing emergency work relief. Under the Social Security Act enacted in 1935, the Roosevelt administration established a federal/state/local partnership to provide public assistance to dependent children, the blind, and the aged that replaced the much smaller state and local programs that had existed prior to the New Deal. Federal involvement in relief efforts led to dramatic increases in spending, as per capita relief expenditures increased by about 160 percent between 1932 and 1933. By 1940 per capita relief expenditures were almost three times the 1932 level even though the unemployment rates were substantially below the 1932 level.

One way to measure the success of these programs is to examine how they influenced demographic outcomes. Economists have become increasingly interested in using a broad range of demographic measures, in addition to income, to determine economic welfare. Infant mortality rates, for example, have been incorporated in alternative assessments of well-being that supplement comparisons of real per capita GDP across countries. ${ }^{1}$ In many situations, including the 1930s in America, we cannot obtain good estimates of the incomes of the poor. Meanwhile, numerous studies show that mortality rates and fertility are strongly associated with socioeconomic status, broadly defined. ${ }^{2}$ Because the relief programs of the New Deal - and welfare programs more generally - were designed to help people in the lower tail of the income distribution, fertility and mortality rates can serve as important indicators of the programs' effectiveness.

Studies of modern U.S. data can give us only limited guidance as to the impact of major Depressions. Christopher Ruhm's (2000) study of the U.S. from 1972 to 1991 finds that mortality rates tend to fall during downturns, but the period he examines does not include downturns of the scale of the Great Depression, and studies of other times and places do not find such a pro-cyclical relationship. Meanwhile, a growing body of research has explored the impact of various modern social programs on the health and development of children. ${ }^{3}$ Focusing on relatively recent expansions in various programs' benefits or the cross-state differences in these benefits, the research has produced a mixed assessment of the effectiveness of modern public assistance. The modern debates over the effect of welfare benefits on 
fertility have focused in particular on teen pregnancies and out-of-wedlock births in an economic environment with relatively mild fluctuations (Haveman and Wolfe 1994, ch. 6; Blank 1995; Mellor 1998; Grogger and Bronars 2001; Schultz 1994). The Depression of the 1930s was so harsh and the introduction of large scale federal spending so new that the effect of social welfare spending was more likely to have encouraged marriage and married couples to return to more normal fertility patterns.

To analyze the impact of the relief programs, we developed a new panel data set that enables us to measure the relationships between relief spending and birth and death rates in 114 cities annually from 1929 through 1940. The U.S. Children's Bureau published annual information on public assistance for 1929 through 1935 (Winslow 1937) and the U.S. Social Security Board updated the series and carried the data forward through 1940 (Baird 1942). To this rich data set on relief spending, we then matched information on demographic outcomes in the cities, as well as socioeconomic variables (see the Data Appendix for details). Thus, the data that we have assembled not only captures the dramatic increase in relief spending that accompanied the New Deal's introduction in the early 1930s, but it also allows us to measure the effectiveness of the relief spending at a relatively low level of aggregation. Analysis of the data using fixed effects to control for heterogeneity and instrumental variables to control for endogeneity suggest that the New Deal relief programs had a substantial influence on demographic outcomes during the 1930s. Greater spending was associated with lower infant mortality, lower suicide rates, fewer deaths from diarrhea and infectious diseases, and higher birth rates. The New Deal relief programs essentially helped contribute to returning society toward more normal demographic patterns in the heart of the worst Depression in American history.

\section{Demographic Trends and the Depression}

The Great Depression not only damaged the economy, but it had a significant demographic impact as well. Birth rates were depressed and death rates elevated relative to the trends seen between 1915 and 1930. Figures 1 and 2 show the national rates from 1915 to 1940 , as well as trend lines derived from linear regressions of the rates on year for the period 1915-1917 and 1919-1929. We eliminated 1918 in 
determining the trend due to the sharp spike associated with the Great Influenza and U.S. participation in World War I during that year. ${ }^{4}$

The Great Depression has always been seen as a period of low fertility, as marriages were delayed and plans for children postponed. This description of the 1930s as the nadir of the birth rate has been driven partially by the rise in fertility during World War II and the baby boom that followed. However, the Depression contributed to lower fertility even if we focus on the trend established between 1915 and 1929. As seen in Figure 1, the general fertility rate (GFR), defined as the number of live births per female aged 15-44, displayed a downward trend between 1915 and 1929. The GFR fell below the earlier trend by the late 1920s and continued to fall even further below the trend until 1933. From 1933 forward the GFR was around 80 live births per thousand before rising strongly through the 1940s and afterward.

The national trends of the infant mortality rate (IMR), defined as the number of deaths of infants under age 1 per thousand live births, show long-term declines prior to the 1930s (Cutler and Meara 2001). The IMR in Figure 1 continued downward through 1932 along the 1915-1929 trend line, yet as the Depression reached bottom in 1933, the IMR rose slightly in 1933 and 1934 and then remained well above predictions from the pre-Depression trend for the rest of the 1930s. Table 1 shows that the general trends experienced nationwide during the 1930s were also experienced in the major U.S. cities which are represented in our data set. ${ }^{5}$

Part of the decline in the IMR prior to the 1930s may have been associated with a decline in mortality rates for all ages. The non-infant death rate (NDR), the number of deaths of people over one year old per 1,000 people in the population, also displayed a marked downward trend between 1915 and 1929. Between 1930 and 1933 the NDR matched predictions based on the earlier trend. As the economy recovered, the NDR rose to a peak near 11 deaths per thousand in 1936 before dropping back to 10 in the late 1930s. In a rough sense the NDR displayed the same kind of pro-cyclical behavior that Christopher Ruhm (2000) documented for the U.S. between 1972 and 1991. The fluctuations in the 1920s and 1930s were negatively correlated with national unemployment rates.

The national averages disguise substantial variation across cities for relief spending and 
demographic outcomes over the course of the decade. The variation shows up in levels across cities. For example, the average infant mortality rate for the 1930s ranged from a low of 30.1 infant deaths per 1,000 live births in Newton, Massachusetts to a high of 104.5 in El Paso, Texas. Further, there is substantial variation across cities in the changes in demographic outcomes and in the changes in relief spending per capita across cities associated with the introduction of the New Deal relief spending in 1933. Figure 3 shows for each city the difference between the average infant mortality rate for the years 1930 through 1932 and the average infant mortality for 1933 through 1940 plotted against the difference in average per capita relief spending for the two time periods. The range across cities in the differences in average infant mortality rates is between 8 per thousand and -30 per thousand, while the changes in average relief spending per capita ranged from $\$ 8$ to $\$ 70$ per capita. In a preview of one of our findings, there is a significant negative relationship between infant mortality rates and per capita relief spending. The differences in relief spending and the differences in infant mortality rates are negatively correlated $(\rho=-$ 0.22). A regression of the change in average infant mortality rates from 1930-1932 to 1933-1940 on the change in average per capita relief led to a statistically significant coefficient of -0.094 . Infant mortality rates for cities in the top quartile of the change in relief spending fell by an average of 11.7, compared with average falls of 10.5 in the third quartile, 9.35 in the second quartile, and 10.3 in the bottom quartile. ${ }^{6}$

\section{Relief Spending During the Great Depression}

The relief programs of the 1930s were designed to bolster the incomes of the unemployed and the non-working poor. Increased relief spending provided immediate access to financial resources that would have enhanced the material well-being of families and their children. Increases in spending on such critical items as food, housing, clothing, or health care likely led to lower infant mortality and perhaps noninfant death rates. The presence of a stronger financial safety net might have contributed to families feeling more secure in returning to their normal fertility behavior.

When the Great Depression struck, provision of welfare and social insurance was the primary responsibility of local governments, with some specific support from state programs. Families in dire 
circumstances might have turned to various sources for assistance. A number of cities provided shelter and food in almshouses, while some cities provided relatively small amounts of cash assistance and in-kind aid to the poor. Private charities often distributed various forms of aid, of which a significant portion was funded by local governments. Nearly all states had established mothers' pensions for women who had lost their spouses and who had dependent children. Injured workers' were covered under workers' compensation laws established during the 1910s. An increasing number of states during the early 1930s instituted old-age pensions that provided limited cash benefits to the elderly and about half the states offered cash benefits to the blind. Some governments tried to provide work for the unemployed through limited public works projects. The aid was administered by social workers, charities, and local officials who tried to assess the recipients' needs and to some extent their “moral worthiness." Prior to 1933 the federal government played almost no role in providing relief spending beyond some aid to veterans (see Skocpol, 1992, ch. 2).

As the unemployment rate rose and income and tax revenues dropped between 1929 and 1933, state and local social welfare resources were quickly overwhelmed. During the fall of 1932 the Hoover administration provided loans through the Reconstruction Finance Corporation to help some cities temporarily fund their relief budgets. Faced with national unemployment rates near 25 percent in 1933, the Roosevelt administration argued that the economy had become a national problem and thus the federal government should accept much greater responsibility for providing relief. In fact, by 1935 the federal government's share of total relief spending had risen to 79 percent from 2 percent in 1932 (see Table 1). Not only did the federal government virtually take over the provision of relief, but the amount of spending jumped markedly. As reported in Table 1, average per capita relief spending in 114 major cities rose from \$18 in 1932 to \$48 in 1934 (1967 dollars), the first full year the federal New Deal was in operation. Table 1 also reports the relative generosity of the relief benefits. For the typical family on relief, benefits never exceeded 42 percent of annual manufacturing wages. So while relief was extremely generous in historical perspective, a private sector manufacturing job certainly would have been more lucrative.

Between July 1933 and June 1935 the primary relief agency was the Federal Emergency Relief 
Administration (FERA). Federal FERA officials distributed funds to state governments through an opaque process in which the revealed distribution suggests that they paid attention to the level of economic distress in the state, the state's entreaties to FERA administrators, the state's own efforts to fund relief, and to some extent the political situation. State governments then distributed the funds internally to local governments. ${ }^{7}$ Once established, the FERA offered both direct relief and work relief. ${ }^{8}$ Direct relief included programs that had no specific work requirements and assistance was provided in cash or in-kind, including subsistence items, such as food, shelter, clothing and household necessities, or medical care and hospitalization. Work relief, as the name connotes, required a labor contribution in return for the benefit. FERA set a series of broad guidelines for its programs, but relied heavily on state and local officials to administer them and to determine the appropriate amounts of relief that individuals would receive. Applicants for relief applied to local offices, where officials met with them personally and determined their eligibility for relief based on a "budget-deficit" principle. That is, local officials determined the deficit between the family's total income and a hypothetical budget for a family of that size. This budget-deficit served as the basis for the family's direct relief benefits or the amount that would be paid for work on a FERA project. The amount of relief actually distributed to a family in many cases fell short of the budgetdeficit if FERA funds in the local area were limited, as local officials sometimes decided to stretch their limited resources by funding more relief cases at less generous amounts.

In response to a harsh winter and high levels of unemployment, FERA activities were supplemented temporarily by the Civil Works Administration (CWA) work relief program from November 15, 1933, through March 1934. Large numbers on the FERA relief rolls were transferred to CWA employment, where they received wages that were not based on the budget-deficit principle. At its peak in January 1934 the CWA employed four million workers, but the program was shut down in March 1934 and many of the workers were shifted on to FERA work relief projects that were soon established. ${ }^{9}$

In mid-1935 the Roosevelt administration redesigned the federal government's role in providing relief. The federal government continued to provide work relief for the unemployed who were "employable" through the Works Progress Administration (WPA), but returned much of the responsibility 
for direct relief of "unemployables" to state and local governments. Applicants for aid were certified by state and local officials, who still considered a family's budget-deficit when assessing its need for relief employment (Howard 1943, 380-403). It was the federal WPA then that hired people from the certified rolls. Dissatisfied with its lack of control over work relief under the FERA, the WPA was administered more centrally by the federal government. The WPA, like its FERA predecessor, specified no hard and fast set of rules for distributing the funds. Econometric studies of the distributions of funding across counties suggest that the WPA administrators paid attention to local economic distress, the lobbying of state and local governments, presidential politics, and the memberships of key congressional committees (see Howard 1943, Fleck 1999a, 1999b, and 2001a, Fishback, Kantor, and Wallis 2003).

The federal government was not completely absent from providing direct relief to "unemployables," as the Social Security Act of 1935 introduced joint state-federal versions of some earlier state programs, such as old-age assistance, aid to dependent children (replacing mothers' pensions), and aid to the blind. Beginning in 1936, federal grants-in-aid became available on a matching basis to states administering approved plans under the Social Security Act. By the end of 1938, all but 8 states were receiving federal grants. The shift in focus of the federal relief efforts and the eventual reductions in federal emergency work relief programs caused the federal share to slowly decline to 57 percent by 1940 .

In performing the analysis we focus on the combined value of all forms of relief rather than try to examine the impact of particular relief programs for two reasons. First, households had access to a variety of sources of relief, and many received funds from multiple programs over the course of the 1930s. Consider a widow with small children. She was eligible for state mother's pensions through most of the 1930s, but she could also apply for aid through the New Deal agencies that determined eligibility by comparing the household's actual income to a target income that relief administrators believed could sustain the family. Since state mothers' pensions were not very generous, and a number of states were slow to adopt the legislation enabling the federal ADC program, it was likely that one-parent households received the bulk of their relief from these other New Deal programs. These interactions with multiple relief programs suggest that any focus on specific programs would mis-measure the impact of relief. 
Second, categorical programs like ADC are too narrowly focused when matched with our measures of demographic outcomes. It has been suggested that the natural focus of the study of relief and infant mortality should be on Aid to Dependent Children and mothers' pensions. In many states mothers' pensions were limited to widows with children, while the federal/state ADC program provided relief for children in households with at least one parent missing. Yet, only 7 percent of the households with infants under age one would have been eligible for ADC or mothers' pensions. ${ }^{10}$ The remaining households with infants, which composed the substantial majority of the households in the infant mortality figures were receiving their relief from other programs.

\section{An Empirical Model of the Demographic Effects of the New Deal}

Our goal is to examine the relationship between relief spending and various demographic outcomes, infant mortality rates, noninfant death rates, cause-specific death rates, and the general fertility rate. We use the same basic modeling procedures for each type of demographic outcome with some changes in choice of correlates to reflect specific situations. Since we believe that infants were the most vulnerable to the impact of the economic downturn and thus infant mortality was more likely to be improved by relief spending, we work through the analysis for the infant mortality rate first to establish the template for the analysis. We then examine the remaining demographic outcomes with adjustments for their specific situations.

We estimate the following infant mortality equation:

$$
\mathrm{IMR}_{\mathrm{it}}=\mathrm{f}\left(\mathrm{R}_{\mathrm{it}}, \mathrm{Y}_{\mathrm{it}}, \mathrm{X}_{\mathrm{it}}, \mathrm{e}_{\mathrm{it}}\right)
$$

where $\mathrm{IMR}_{\mathrm{it}}$, the number of infant deaths per 1,000 live births in city i in year $\mathrm{t}$, is modeled as a function of relief spending in city $i$ in year $t\left(R_{i t}\right)$, economic activity $\left(Y_{i t}\right)$, a vector of demographic characteristics $\left(X_{i t}\right)$, and random error. Because income data at the city level do not exist for the 1930s, we use per capita retail sales in the county in which the city was located as our measure of economic activity. Retail sales are clearly an important measure of macroeconomic activity because even today the U.S. Bureau of Economic Analysis uses retail sales figures to create annual estimates of personal consumption of durable and 
nondurable goods for the National Income and Product Accounts (U.S. Bureau of Economic Analysis 1987, 11). Comparisons of annual national aggregates of retail sales and all personal consumption expenditures over the period 1929 through 1969 show correlations above .99 for the levels of the series (in both real and nominal terms), .96 for first differences of the nominal values, and .91 for first differences of the real values (U.S. Bureau of the Census 1975, series T79, G416, G417, G418, and E135). Retail sales also are strongly related to personal income. Correlations of state-level per capita personal income and retail sales for the years $1929,1933,1935$, and 1939 are $.87, .89, .88$, and .90 , respectively. The X vector contains a series of demographic factors that were likely to influence infant mortality patterns. These include the percent black, percent foreign-born, and percent illiterate to capture ethnic and racial differences in income and cultural practices toward raising infants. To control for the differences in health and maturity among the potential child-bearing population in the infant mortality and general fertility equations, we include the percentages of women in their prime child-bearing years, separated into age categories $15-19,20-24,25-29,30-34$, and 35-44. In the equations for noninfant deaths and the various causes of death we controlled for the influence of age differences for the entire population by including the percentages of the population ages 10-19, 20-30, 30-34, 35-44, 45-54, 55-64, and 65 and up. Finally, we also include the percent urban for each observation. For a number of observations, the district covered in the reporting of relief was the entire county in which the city was located. In those counties, therefore, we used county information for infant mortality as well. Some of these counties contained rural populations and, thus, it was important to control for the extent of urbanization within the county. In other observations, city-level relief data were reported and the level of urbanization in these cases was obviously 100 percent.

The relationship between per capita relief spending per capita and the infant mortality rate is negative under a variety of econometric estimation procedures. Table 2 reports the coefficients and tstatistics of the relief variable under a variety of specifications, and also includes the number of standard deviations by which infant mortality changed in relation to a one-standard-deviation (OSD) increase in per capita relief. Changes of one standard deviation are fairly common events, and thus the OSD measure is a 
good measure of the historical explanatory power of changes in relief spending. The coefficients and ttests for all of the correlates in the OLS specification with and without city and year effects are reported in Table 3.

The baseline OLS coefficient suggests that a $\$ 1$ increase in per capita relief was associated with a 0.32 reduction in the infant mortality rate. The addition of a series of controls for economic activity (retail sales per capita) and demographic differences across cities causes a reduction in the coefficient to 0.27 .

Yet, there still remain a large number of unmeasured factors, like public health and sanitation programs, that varied across cities in ways that likely are biasing this coefficient in the negative direction. Our sense is that cities with better public health and sanitation were also more likely to spend on relief themselves and lobby more effectively for relief spending from the federal government. The combination of the positive correlation between public health and relief programs and the negative correlation between public heath activity and the infant mortality rate would bias the OLS coefficient downward. We therefore include city effects to control for the time-invariant components of public health and sanitation, as well as local customs and attitudes, regional diets, availability of medical care, cost of living, climate, or other factors within the city that did not change over time. We also incorporate year effects to control for shocks to the national economy or technological changes in health care, like new vaccines, that all cities experienced. The results in Table 2 show that the addition of the fixed effects substantially reduces the magnitude of the coefficient to -0.032 , and is statistically significant at the 10 percent level in two-tailed tests. A one-standard-deviation (OSD) increase in relief spending reduced the infant mortality rate by 0.05 standard deviation.

The long-term downward trend in the national infant-mortality rates raises the possibility that the impact of the rise of relief spending in the 1930s on infant mortality in the cities may be capturing just a continuation of the downward trend from the 1920s. Following work by Werner Troesken (2004), we have addressed this issue by developing city-specific predictions of the trend in the IMR based on the patterns displayed between 1921 and 1928 in each city. Linear regressions of the infant mortality rate on 
the year were run in each city with four or more observations for the period 1921 through 1928 to develop trend rate predictions for infant mortality rates in each city from 1929 through 1940. Due to lesser coverage of the death and birth registration areas in the 1920s, the trends could be determined for only 97 cities. ${ }^{11}$ Of the 97 cities, 87 displayed negative trends between 1921 and 1928, of which 81 trends were statistically significant at the 10 percent level. Table 2 shows the fixed effects results for 1929 through 1940 for this group of 97 cities both excluding and including the predictions from the prior trend. Controls for the prior trends in the various cities have little impact on the estimates of the impact of relief. In the subsample of 97 cities, the relief coefficient is -0.037 without the trend control and -0.036 when the trend control is included; and both coefficients are similar to the fixed effect coefficient for the entire sample. The addition of controls for prior time trends had little effect on the relief coefficients and hypotheses tests in all of the various estimation procedures for infant mortality rates, general fertility rates, and noninfant death rates that follow. Since the control for prior trends have little impact on the relief coefficients and inclusion reduces the sample of cities substantially, we focus on the results without the time-trend controls in the rest of the paper. Results with the time-trend controls are available from the authors. $^{12}$

Even after controlling for the fixed effects and prior trends, there might remain another channel for endogeneity. Although the retail sales measure controls for changes in general economic activity during the 1930s, we still may be missing differential shocks to incomes and other factors for the poorest segment of the income distribution. People in the lower tier of the income distribution, in particular, were more likely to experience health problems in response to negative shocks given their low starting level of income. Studies of more recent data within the United States (Kaplan, et. al,1996, and Kennedy, Kawachi, and Prothrow-Stith 1996) find that greater income inequality is associated with worse health outcomes and risky behaviors. If the absence of an income inequality measure were to create problems with endogeneity bias in the OLS with fixed effects analysis, there would need to be variation in poverty across time within cities and/or across cities for a specific year in ways unrelated to the retail sales measure. Such unmeasured shocks for the poor were likely to be associated with greater relief spending and also with 
higher infant mortality and death rates. The combination of these two positive correlations would be likely to lead to a positive bias in the relief coefficient in the fixed effects equation that would cause the coefficient to understate how much relief spending lowered the death rate. To address this potential channel for endogeneity, we have developed an instrumental variables approach.

Decisions about the extent of relief spending during the 1930s were made in a complex interaction between federal, state, and local decision-makers. Unlike the modern federal system with precisely specified rules for distributions, New Deal administrators distributed funds through an opaque process. ${ }^{14}$ As a result, an extensive literature on the political economy of New Deal spending has developed to try to understand the factors that influenced the distribution of New Deal funds (see, e.g., Wright 1974, Wallis, 1998, 2001, Couch and Shughart 1998, Fleck 1999a, 1999b, and 2001b, and Fishback, Kantor and Wallis 2003). We have used this literature to guide our choice of instruments. One key finding in the literature has been that the Roosevelt administration appears to have used the distribution of funds to enhance its reelection chances. A variety of presidential voting measures have been explored in these studies, but nearly every one finds that the Roosevelt administration distributed New Deal funds in an attempt to attract swing voters who were needed to ensure re-election. The typical measure of swing voting that has been used is the standard deviation of the percent voting for the Democratic candidate in presidential elections over an extended period of time. Robert Fleck (1999b) used this variable as an instrument in studies of the marginal effect of relief spending on county unemployment rates. A higher standard deviation suggests greater volatility in voters' support for the Democrats and an indication that a larger percentage of the voting population could be swayed to switch party loyalties from year to year. Since New Deal administrators updated relief spending decisions periodically, they likely updated their estimates of the volatility of Democratic support after each election. We therefore update the swing-voting measure after each presidential election. Thus, for observations from years up to and including 1932, we calculate the standard deviation of Democratic voting using the election years from 1896 through 1928. For observations from the years 1933 through 1936, we calculate the standard deviation from the elections from 1896 through 1932. Observations in years 1937 through 1940 use election results from 1896 through 
1936.

In addition to the presidential swing measure, we have included measures of the influence of politicians in Congress and at the state level. Gary Anderson and Robert Tollison (1991) suggest that Congressional representatives on key committees were likely to influence the distribution of funds. Fishback, Kantor, and Wallis (2003, 299 note 21) find that members of the Labor committee in the House of Representatives, in particular, influenced the distribution of federal relief monies across counties. The Labor committee was the primary committee that was devoted to unemployment issues during the New Deal. We explored inclusion of measures of representation on the Appropriations and Ways and Means committees that controlled the purse-strings and taxing authority in the House, but neither of these committees contributed any explanatory power to the first-stage regressions.

To capture political influences at the state level, we created a dichotomous variable that takes the value 1 if the governor was a Democrat and zero otherwise. In lobbying for federal relief funds, governors from Roosevelt's party were likely to have better access to funds and Democratic governors, controlling for the South, historically were more likely to advocate greater social insurance spending.

For the instruments to be effective, they must have an impact on the distribution of per capita relief even after controlling for other measurable exogenous variables in the system and they must be uncorrelated with the error term in the second-stage death rate (or fertility rate) equation after controlling for the other measured correlates. It is certainly possible that any of the political variables could display raw correlations with death rates and fertility rates. However, the controls for economic activity, ethnic minorities, age distributions, city, and year are already capturing many of the avenues through which we would normally expect election outcomes to be correlated with death rates and fertility. One worry is that the measures of political activity would be correlated with the unmeasured poverty that we believe may be contributing to endogeneity. The political measures are unlikely to be correlated with unmeasured poverty for the following reasons. First, numerous electoral studies suggest that the poor tend not to have much political clout in elections either because they often choose not to vote or are implicitly or explicitly disfranchised (see Kousser 1974, Lijphart 1997). Thus, unmeasured income shocks to the poor were likely 
well down the list of the major issues that were decisive in presidential, gubernatorial, and congressional elections. Second, we have chosen instruments with either temporal, spatial, or institutional distance from the city for each city-year. The information on presidential voting is for a long string of years prior to the observation year to avoid temporal simultaneity bias. The gubernatorial instrument focuses on the state's political climate and not the specifics within the city. House committee representation has institutional distance due to the committee assignment process in the House of Representatives. Since we cannot be sure that the unmeasured factors are not correlated with the instruments, we seek to allay concerns further by performing tests of whether the instruments have been inappropriately omitted from the second-stage equation in a statistical sense.

We have explored the use of a variety of potential instruments that have been discussed in the New Deal literature, but we focused on the presidential swing-voting, House Labor committee, and Democratic governor instruments because they meet the following criteria in estimations of the model with fixed effects. First, as discussed above, we believe that the instruments are exogenous and not themselves influenced by relief spending or infant mortality. Second, the coefficients of the instruments have the predicted positive signs in the first-stage relief regression and the effects are both economically and statistically significant. Third, using a Hausman (1983, 433; see also Greene 2003, 413-14) test we could not reject the hypothesis that the group of identifying instruments were uncorrelated with the 2SLS estimates of the error term in the second-stage infant mortality equation. The test results suggest that the identifying instruments have not been inappropriately omitted from the second-stage infant mortality equation. ${ }^{15}$

Table 3 shows the first-stage relief and the second-stage infant mortality regressions. Under both specifications the coefficients for the three instruments have the expected positive signs. More relief funds were distributed to cities with greater volatility in their support for Democratic presidential candidates, with more representation on the House Labor committee during the New Deal, and located in states with Democratic governors. The coefficients of these variables are statistically significant, and the F-statistic for the joint hypothesis that all three coefficients are zero is 17.17. The results of the Hausman tests are 
consistent with the view that the identifying instruments have not been inappropriately omitted from the infant mortality equation. ${ }^{16}$

The relief spending coefficient in the 2SLS estimation is statistically significant at the 10 percent level and negative. An additional dollar of per capita relief spending was associated with a reduction of 0.16 infant deaths per 1,000 live births, while an OSD increase in relief spending per capita reduced infant mortality by 0.27 standard deviation. The difference between the OLS and 2SLS fixed-effects coefficients is consistent with the predicted positive endogeneity bias in the OLS estimates associated with unmeasured economic shocks that hit the poor in ways that were not fully measured by the retail sales variable. Thus, it appears that the OLS fixed-effects estimate of -0.032 is a lower bound of the inverse effect of relief spending on infant mortality rates.

In one sense the results in Tables 2 and 3 can be considered reduced-form estimates from a structural demographic model in which the infant mortality rate is also a function of the general fertility rate and the non-infant death rate. In a number of settings demographers have found positive relationships between the infant mortality rate and the fertility rate and non-infant death rate, respectively. Increases in birth rates may lead to reductions in intervals between births with the consequence of less maternal care available per child and shorter durations of breast feeding, both of which contribute to poorer infant health. ${ }^{17}$ Infant and non-infant death rates are likely to be positively related to the extent that the two age groups were struck by the same contagious diseases or faced similar environmental hazards. ${ }^{18}$ Thus, it is possible that the omission of the non-infant death rate and the birth rate from the specification causes the relief coefficient to capture the effects of changes in these other demographic variables that may have also contributed to declines in infant mortality.

To investigate this issue further, we re-estimated the models with the fertility rate and the noninfant death rate included as controls to isolate the impact of relief on infant mortality outside the birth rate and non-infant death rate channels. ${ }^{19}$ To aid in comparing the results, we have included in Table 2 all the coefficients and t-statistics of the relief spending variable from specifications with and without the birth and non-infant death rates. Comparisons of the results show little difference in the impact of relief 
spending on infant mortality whether or not we control for the birth and non-infant death rates. In each comparison, except for the OLS comparisons with no controls for any other factors, the difference in coefficients is substantially less than 8 percent. Thus, it appears that the finding that relief spending reduced infant mortality is not driven by a secondary influence of relief spending on birth rates or noninfant death rates.

Although the magnitudes vary, each specification suggests that relief programs were successful in alleviating the economic and resulting physical hardship for infants that resulted from the Great Depression. This finding is similar to our earlier findings that the federal relief programs and public works programs contributing to lowering infant mortality in the southern states, particularly in black families (Fishback, Haines, and Kantor, 2001). In that earlier study we did not have measures of state and local relief funding and thus could examine the impact of all forms of relief spending.

\section{Noninfant Death Rates}

To the extent that infants are more vulnerable to changes in economic circumstances than the rest of the population, we do not anticipate that relief spending will have as large an effect on the noninfant mortality rate. The rate is measured as the number of deaths of people over one year old per thousand people in the city. The results in the top two rows in Table 4 show the OSD effects and the t-statistics associated with the relief coefficients when we follow the same estimation procedures found in the infant mortality analysis. Since the rate is for the entire population, the age controls have been changed to reflect the shares of the entire population at ages 10-19, 20-29, 30-34, 35-44, 45-54, 55-64, and 65 and up.

The baseline OLS result without other correlates shows that increased relief spending was associated with lower non-infant death rates. An OSD increase in relief spending was associated with a 0.116 standard deviation reduction in the non-infant death rate. As in the case of infant mortality, as more correlates and fixed effects are added, the size of the relief effect is reduced. In the OLS analysis with city and year effects, the relief coefficient is statistically significant in two tailed tests at only the 15 percent

level, and an OSD increase in relief spending would have reduced the death rate by only .026 standard deviation. When we perform the 2SLS analysis, the coefficient increases in absolute magnitude, such that 
the OSD effect increases in magnitude to -0.099. However, we cannot reject the hypothesis of no effect.

Some of the impact of relief on the noninfant death rate may have been operating through changes in fertility rates and infant mortality rates. For example, higher fertility rates meant that more women were at risk of maternal mortality and there may have been contagion cross-effects from infant mortality rates. When we add controls for these rates (see rows 3 and 4), the coefficient of relief spending is no longer negative and statistically significant in any of the specifications. In the fixed effects analyses the relief coefficient is extremely small. Meanwhile the 2SLS analysis suggests a very strong but statistically insignificant effect of relief on the noninfant death rate.

\section{The Impact of Relief and General Economic Activity on Specific Causes of Death}

The lack of statistically significant effects of relief spending on the non-infant death rate is likely to arise because the non-infant deaths include a wide variety of causes of death. Some causes of death are less likely to be reduced by the better access to nutrition, housing, health information, or medical care that relief payments afforded. For example, most studies suggest that death rates due to cardiovascular disease are not reduced much for people with higher incomes. In fact, an increase in income might have led to higher death rates because the person might be more likely to overeat, eat more fatty foods, or drink more alcohol (Ruhm, 2000). Non-infant deaths included deaths from motor vehicle accidents, on which relief might have had conflicting effects. The resources provided for relief might have lowered the death rate for motoring accidents as the person now had more resources to better maintain the safety of the automobile. On the other hand, more resources might have allowed the person to drive more often, thus exposing him to a greater risk of having a fatal accident during the course of the year.

To explore the impact of relief spending on specific causes of non-infant deaths, we examine death rates for specific causes of death for the period 1929 through 1937. We could not extend the data set to 1940 because the census stopped reporting the cause of death data for individual cities when it revamped its publications in 1938. There is likely to be more measurement error in the estimation of the effect of relief because the cause of death data was available only for the cities, while the relief spending information for roughly half the sample was for the county in which the city was located. The causes of 
death are grouped into 11 categories: homicides; suicides; respiratory tuberculosis; other infectious and parasitic diseases; neoplasms (malaria and cancer and other malignant tumors); cardiovascular disease; a grouping of influenza, bronchitis and pneumonia; diarrheal diseases; degenerative diseases; deaths in motor vehicle accidents; and maternal mortality.

Suicides and homicides are of particular interest in this list because, unlike nearly all of the other causes of death, they are based directly on specific decisions, rational or irrational, that individuals made. Suicide focuses specifically on mental health issues for the people who take their own lives, while the taking of another life in a homicide is often stimulated by stresses within families, neighborhoods, or locations that can be economic in nature. Recent studies of modern data for the U.S. and other economies suggest that suicide rates are lower in areas with better economic opportunity and less inequality. A number of studies, but not all, find the same result for homicides. ${ }^{20}$ To the extent that relief spending provided replacement income and jobs on work projects, they were likely to ease some of the economic tensions and material inequality that might have led to more homicides and suicides. On the other hand, the social stigma of having to rely on relief might have contributed further to the stresses and strains related to lost work and income in ways that potentially offset such benefits.

Table 4 shows the results of OLS, OLS fixed effects, and 2SLS with fixed effects estimation for the various causes of death. In the simplest comparisons where the death rate is estimated as a function only of per capita relief spending, we find a negative relationship for all the causes of death except for deaths due to neoplasms and cardiovascular disease. Once the city and year effects control for differential access to long-term sanitation and public health facilities across cities, negative relationships are still present for roughly half of the disease categories, including homicides, suicides, diarrheal diseases, degenerative diseases, motor vehicles, and influenza, bronchitis, and pneumonia. As in the infant mortality section, there may be worries that the inability to fully control for the shocks to the very poor might lead to a positive bias in the relief coefficients. Modern studies show that homicide rates, for example, are associated with greater poverty and we expect that more poverty was associated with greater relief spending. ${ }^{21}$ As expected, the negative impact of relief on homicides and suicides increases when using 
2SLS estimates to try to control for this potential bias. The 2SLS estimates suggest that an OSD increase in relief spending lowered the homicide rate by 0.21 standard deviation, although the relief coefficient in the homicide analysis is only statistically significant at around the 15 percent level. The OSD effect for suicides was substantially larger at -0.85 standard deviation and the effect is statistically significant. When we consider that suicides and homicides are relatively extreme manifestations of the strains and pressures associated with economic Depressions and that the programs were not targeted specifically toward mental health or crime problems, relief appears to have had a material influence on the poor's well-being.

Only two other causes of death were reduced by greater relief spending in the 2SLS estimation, deaths from infectious and parasitic diseases and diarrheal deaths. The 2SLS OSD effects of relief spending were -0.576 and -0.383 , respectively. Relief spending may have staved off death for those struck by the diseases by providing better nutrition, access to medicine, and protection against the elements. To the extent that relief spending allowed people to stay in better housing, it allowed households to isolate the victims of disease and thus limit its spread to other family members. Both diseases are considered by demographers to be acute diseases that would likely be responsive to immediate reductions through greater relief spending, while many of the remaining diseases were degenerative or long-term diseases that would have been less responsive.

Although we have focused on the impact of relief spending, the analysis also offers the opportunity to look at the impact of retail sales, our measure of economic activity, on the various death rates. Table 5 shows the OSD effects of retail sales per capita on the various causes of death for both the OLS fixed effects and the 2SLS analyses above. Some caution should be used in interpreting these results because we have made no attempt to control for potential endogeneity between the death causes and retail sales per capita. However, we do not anticipate that there was a strong direction of causation that ran from death rates to retail sales per capita. If there were any, it is likely that the coefficient would have a negative bias.

The coefficient estimates of the impact of retail sales per capita are positive and statistically significant for the non-infant death rate, the homicide rate, respiratory tuberculosis, neoplasms, infectious and parasitic diseases, neoplasms, degenerative diseases, maternal mortality, and motor vehicle accidents. Suicides were 
the exceptions to the rule, displaying negative and statistically significant relationships with retail sales per capita. These pro-cyclical findings for most causes of death and the counter-cyclical findings for suicide rates are similar to Ruhm's (2000) findings for a much later period in the twentieth century. The findings for both the milder changes in the 1970s and 1980s and in the Great Depression lend credence to the possibility that many death rates may have been procyclical throughout the course of the century. ${ }^{22}$

Comparisons of the signs of the effects for retail sales per capita and for relief per capita suggests that the mechanism by which relief spending reduced death rates differs from just simply increasing income for society as a whole. Infant mortality rates were not influenced by changes in general economic activity but they were reduced by relief spending targeted at the unemployed and the poor. Similarly, the non-infant death rate and homicide rates increased in response to general economic activity while declining to some extent in response to relief spending. Of the key rates we have identified, only suicide rates appeared to respond in the same manner to increases in general economic activity and relief spending.

\section{Relief Costs per Life Saved}

One way to measure the effectiveness of relief in reducing death rates is to calculate the magnitude of relief spending associated with saving a life and compare it to economic measures of the value of a life. Table 6 contains estimates of the relief cost per life saved for the various death rate measures where the OLS fixed effects and/or the 2SLS fixed effects estimates are negative and statistically significant at the 20 percent level.

We illustrate the derivation of the measure using the infant mortality rate, which requires more complicated calculations than the non-infant death rates or the death rates for specific causes of death. Consider the 2SLS coefficient with fixed effects for the entire sample from Panel A in Table 2, which suggests that an additional per capita dollar of relief spending would have lowered the number of infant deaths by 0.163 per 1,000 live births.

The number of infant deaths (I) can be written as

$$
\mathrm{I}(\mathrm{r})=\mathrm{IMR}(\mathrm{r}) * \mathrm{GFR} * \mathrm{~W} 1544 * \mathrm{P}
$$


where IMR is the infant mortality rate, GFR is the general fertility rate (births per women aged 15 to 44), $\mathrm{W} 1544$ is the share of the total population composed of women aged 15 to $44, \mathrm{P}$ is the total population, and $r$ is per capita relief spending. Differentiating with respect to $r$,

$$
\mathrm{dI} / \mathrm{dr}=\mathrm{dIMR}(\mathrm{r}) / \mathrm{dr} * \mathrm{GFR} * \mathrm{~W} 1544 * \mathrm{P}
$$

gives a measure of the direct effect of added relief spending on infant deaths. After rearranging terms and setting $\mathrm{dI}$ equal to 1 , we can determine the amount of relief spending associated with a reduction of one infant death $(\mathrm{dR})$, the change in per capita relief spending $(\mathrm{dr})$ times population $(\mathrm{P})$,

$$
\mathrm{dR}=\mathrm{dr} \mathrm{P}=1 /(\mathrm{dIMR}(\mathrm{r}) / \mathrm{dr}) * \mathrm{GFR} * \mathrm{~W} 1544) \text {. }
$$

Using the 2SLS with fixed effects coefficient for dIMR/dr of -0.163 and sample means for the other variables in equation (3), an additional $\$ 153,045$ of relief spending (1935 dollars) - or roughly $\$ 1.95$ million when adjusted to year 2000 dollars - would have been associated with saving an infant's life. The estimate of the relief cost per life saved is higher at $\$ 8.61$ million when we focus on the OLS with fixed effects estimate.

The relief costs per life saved based on the 2SLS coefficients for the population over one year old and for specific causes of death are in the same ballpark as the costs per infant life saved. The relief cost per life saved is $\$ 4.5$ million for homicides, $\$ 1.9$ million for suicides, $\$ 840$ thousand for infectious and parasitic diseases, and $\$ 1.76$ million for diarrheal diseases. As was the case for the infant mortality rates, the OLS fixed effects coefficients imply much higher relief costs per life saved, which might be considered an upper-bound on the relief cost per life saved.

The estimates based on the 2SLS coefficients are roughly comparable to modern estimates of the market valuations of life, which range from about $\$ 1$ million to $\$ 9.5$ million. ${ }^{23}$ Some care must be exercised in making comparisons to market values of life for infant lives saved because these estimates have been calculated for working adults. Thus, it is useful to compare the costs to other social welfare programs that more directly target children. Currie and Gruber (1996b) estimated that targeted changes in the modern Medicaid system that lowered the eligibility requirements for specific groups spent $\$ 840,000$ to save an infant life. Of course, this estimate focused on specific changes in Medicaid that would have 
had a direct impact on children's health. When Currie and Gruber examined the impact of broader changes in the Medicaid program not specifically targeted at high-risk groups, the cost per life saved was about $\$ 4.2$ million. These comparisons suggest that during the economic crisis of the Great Depression, the flood of relief spending was roughly as cost effective in saving infant lives as modern Medicaid spending.

It is important to remember that the purpose of relief spending during the Great Depression was not simply to prevent infant deaths, suicides, homicides, or other deaths. This outcome was one of a number of welcome effects associated with alleviating economic hardship among the unemployed. For example, Fishback, Horrace, and Kantor (forthcoming, 2005) find that an additional dollar of federal relief and public works grants in a county was associated with an 84 cent rise in income. Once these other benefits of relief spending are taken into account, in comparison to the modern Medicaid program, it appears that relief spending during the 1930s was relatively effective in enhancing the material well-being of infants.

One way to make comparisons with the targeted programs is to consider what share of the relief population was at risk of an infant death, a homicide, or a suicide. As an example, we consider here the infant population, which is much easier to measure than the population at risk of homicides or suicides. Given that people of all ages were experiencing significant problems during the Depression, a relatively small percentage of the relief spending was likely to have been devoted to infants. In an October 1933 census of relief families conducted by the Federal Emergency Relief Administration (1934, 122-43), roughly 1.5 percent of the people whose families were on relief in cities with populations over 100,000 were under the age of one. The infants' share of the relief population in large cities was roughly the same as their share of the overall city population in the 1930 population census. Since relief administrators based the amount of relief on deficits in household budgets, it seems reasonable to assume that infants were allocated a share of overall relief spending equal to their share of the relief population. Under this assumption, infants on relief would have received about 1.5 cents from each additional per capita relief dollar spent in a city. Multiplying this 1.5 percent share by the relief dollars spent per infant life saved, we 
find that of the $\$ 1$ to $\$ 9$ million (in year 2000 dollars) in general relief funds needed to save an infant life, only $\$ 15,000$ to $\$ 135,000$ in targeted relief funds was likely to have been necessary in saving a baby’s life.

\section{General Fertility Rates}

While relief generally had negative effects on death rates, it was associated with higher birth rates. The issues relating relief spending and fertility rates were in many ways different from the modern discussions of welfare and fertility. The modern literature often focuses on tests of the impact of welfare generosity on the fertility behavior of teens and young adults and finds relatively small effects (Haveman and Wolfe 1994, ch. 6; Blank 1995; Mellor 1998; Grogger and Bronars 2001; Schultz 1994). Never-wed single mothers faced much greater social ostracism in the 1930s and had limited access to public funds. The state mothers' pension programs in many states made few provisions for never-wed mothers, focusing instead on widowed mothers (Skocpol 1992). As seen in Figure 1, the drastic declines in economic activity during the early 1930 s coincided with a sharp drop in the general fertility rate, the number of live births per woman aged 15 to 44 . The average general fertility rate in our sample of cities followed a similar pattern, falling from 69.4 in 1930 to 56.7 in 1933 as real GDP fell drastically, as marriages were

postponed. ${ }^{24}$ As the economy began to recover and per capita relief spending increased, the general fertility rate returned to around 62 by 1940 . We anticipate that the effect of relief spending in this environment was likely to encourage couples to return to their normal fertility decisions than it was to give incentives to single women to have children.

The bottom part of Table 4 shows the results from the same series of estimation procedures and specifications (OLS, OLS and fixed effects, and 2SLS with fixed effects) that we had used for the infant mortality equations. Estimates are reported with and without controls for the infant mortality rate and the noninfant death rate. The one difference in the 2SLS specifications was that the instrument set was limited to the presidential voting volatility and the House Labor committee measures. We removed the Democratic governor instrument from the analysis because in all cases when it was included the Hausman test rejected the hypothesis that the error in the second-stage general fertility equation was uncorrelated 
with the instruments. When the governor variable was excluded, the Hausman test no longer rejected the hypothesis.

Although the rise in relief spending coincided with an increase in the general fertility rate at the national level, the baseline OLS coefficient with no correlates for our city sample suggests a negative relationship. A negative cross-sectional relationship between relief spending and the general fertility rate appears to be causing this negative relationship. Once we control for city and year fixed effects, the relief coefficient becomes positive and statistically significant at the 10 percent level, although it has relatively little explanatory power, as an OSD change in relief per capita only raises the general fertility rate by 0.05 standard deviation. The 2SLS estimates lead to coefficients that are statistically significant and larger and positive. The impact of a one-standard-deviation increase in relief per capita was associated with a 0.82 standard deviation increase in the general fertility rate. The impact of more relief spending on the general fertility rate is likely operating through the same channel as an improvement in general economic activity. OSD changes in retail sales per capita also have a large and positive effect on the general fertility rate of between 0.35 and 0.41 standard deviations. Thus, the combination of an improving economy and a more substantial social insurance net contributed significantly to the leveling off of the fertility rate in the late 1930s.

The sharp increase in the relief coefficient in moving from fixed effects to 2SLS is likely driven in part by two negative endogeneity biases in the OLS fixed effects estimates. First, as was the case for the death rates, the absence of good measures for the impact of the Depression on the poor might lead to negative endogeneity bias in our estimates of the impact of relief on the general fertility rate. Unmeasured negative shocks to the poor were likely to lead to lower birth rates at the same time as they would lead to more relief spending. Second, the 1930s saw rapid growth in the family planning movement. Many of the obstacles to birth control and family planning were eliminated by the end of the 1920s and the number of family planning clinics nationwide rose from 28 in 1929 to 374 by 1938 (McCann 1994, 215-217 and Chapter 6). Although we have not been able to obtain information on the timing of the introduction of the clinics across cities, the literature on family planning suggests that a significant number of social workers 
who became New Deal relief workers were interested in family planning; therefore, we anticipate a positive correlation between the clinics and relief spending and a negative relationship between the clinics and the general fertility rate that combined would lead to the negative bias that was eliminated by the use of the 2SLS procedure.

\section{Concluding Remarks}

The Great Depression of the 1930s provides a unique opportunity to test the impact of social welfare spending on demographic outcomes because the economic crisis was so severe and the government's response was equally unprecedented. Given the depth of the depression from 1929 to 1933 and the unusually high unemployment rates throughout the decade, the decade could well have become a demographic disaster with rising infant mortality and non-infant death rates and declining fertility throughout the decade. The national aggregates show, however, that the infant mortality rate stopped falling temporarily in the mid 1930s before continuing on a downward trend. The non-infant death rate stayed on trend through the early 1930s and then rose above trend in the late 1930s, while the general fertility rate fell below trend in the early 1930s before leveling out in the late 1930s. What can explain these puzzling patterns?

A key factor in the explanation of all three patterns is the sharp increase in relief spending during the 1930s when the federal government stepped in to combat the problems of the unemployed and the poor. In essence, federal relief spending provided a safety net for the unemployed and the poor that contributed to a decline in mortality rates for infants under age one, the population most vulnerable to the

effects of economic downturns. ${ }^{25}$ Similarly, increased relief spending was associated with increases in the general fertility rate that allowed households to return to more normal fertility patterns.

Relief spending had no statistically significant impact on overall non-infant death rates because the effects of economic downturns and social insurance varied for different causes of death. Increased relief spending contributed to reductions in the suicide rate, deaths due to infectious and parasitic diseases, and deaths from diarrheal diseases. There is also evidence that greater relief spending reduced homicide rates 
although the effects are less precisely estimated. Increases in relief spending had little or no negative effect on many causes of death where improvements in the standard of living had little impact.

The effect of fluctuations in economic activity during the 1930s mimicked a pattern found by Ruhm (2000) for the modern U.S. economy. The overall non-infant death rate and the fatality rates for homicide rates, infectious and parasitic diseases, cancers, degenerative disease and motor vehicles all displayed pro-cyclical patterns, falling when the economy plunged and rising during the recoveries. A key exception during the 1930s and the modern era was the suicide rate, which tended to be counter-cyclical.

The differences in impact of relief and broader measures of the economy for many of the death rates show that relief spending, which was targeted at the poor and unemployed, had effects that went beyond just improving the general economy. Spending more on relief reduced infant mortality, diarrheal death rates, homicides, and infectious and parasitic diseases, when none of these rates were reduced by changes in our measure of broader economic activity. Only in the case of suicide rates did relief spending and broader improvements in the economy have the same negative effect during the 1930s. One measure of the success of relief spending is the relief cost per life saved. In cases where relief spending lowered a specific cause of death, comparisons show that the relief costs per life saved were similar to modern economic estimates of the value of life. Even though relief programs were targeted at a broad range of social and economic problems, they display similar costs per life saved as modern programs that are targeted more specifically at reducing mortality, such as Medicaid. Thus, it appears that relief programs during the 1930s succeeded in a relatively cost effective manner at offsetting the worst features of the demographic outcomes associated with the Great Depression. 


\section{Data Appendix}

The sample consists of annual observations for 114 cities between 1929 and 1940 . The sample constituted the specific 114 cities because information on relief spending each year from 1929 through 1940 were available in a unique source. The sample includes 49 of the top 50 cities and 87 of the top 100 cities in terms of population. The smaller cities added for geographical balance tended to be outside of the Northeast. The data collection project was initiated in 1929 at the Russell Sage Foundation and was later transferred to the U.S. Children's Bureau, which collected the relief information and published a volume covering the period 1929 through 1935 (Winslow 1937). The project was transferred again to the Social Security Board, which updated the series and carried the data forward through 1940 (Baird 1942). The aggregate population of the sample cities accounted for 37 percent of the total U.S. population and 66 percent of the total urban population.

The city-level relief information was then matched to data on infant and non-infant mortality and birth rates from U.S. Bureau of the Census (1934a, b, c; 1936a, b; 1937; 1938; 1939; 1940; 1941; 1942). The relief spending for a number of the urban areas was reported for the entire county in which the city was located, but just for the city in other cases. Since we had both city and county information on mortality and births rates, we were able to use city infant mortality rates for the cities that reported relief spending only for the city and county information for urban areas that reported relief spending for the entire county.

We sought an effective method of controlling for the substantial changes in income that occurred during the time period. In the absence of estimates of per capita income at the city level, we chose retail sales per capita in the county or counties in which the city was located as a proxy. As discussed in the text, retail sales are strongly correlated with consumption and with income, particularly in urban areas, and we had retail sales information for the counties in which the cities were located for 1929, 1933, 1935, and

1939. Retail sales from 1929 and 1939 are from ICPSR file number 0003, as amended and corrected by Michael Haines. Retail sales in 1933 and 1935 are from U.S. Department of Commerce, Bureau of Foreign and Domestic Commerce $(1936,1939)$. The population estimate used to create the per capita 
measure was based on straight-line interpolations between 1920, 1930, and 1940 data from the amended ICPSR file 0003. We interpolated values of per capita retail sales in the intervening years using estimates of state personal income from the U.S. Bureau of Economic Analysis (1989). For each year between 1930 and 1940, we divided state personal income by an estimate of state population. Then to interpolate per capita retail sales between the benchmark years of 1929, 1933, 1935, and 1939, we used a formula like the one below for 1931:

$$
\mathrm{R}_{31}=\mathrm{S}_{31} *\left(0.5 * \mathrm{R}_{29} / \mathrm{S}_{29}+0.5 * \mathrm{R}_{33} / \mathrm{S}_{33}\right)
$$

where $R_{t}$ is per capita retail sales in year $t$ for the county in which the city was located and $S_{t}$ is per capita state personal income in year $\mathrm{t}$.

We sought to control for other demographic characteristics of the cities, such as ethnicity, nativity, illiteracy, and the extent of urbanization. Given the nature of the available data, these variables are measured at the county level. The exception is that if the relief data was reported for a specific city, and not just the county containing the city, we set the percent urban equal to 100 . The information for 1930 and 1940 is from the amended ICPSR file number 0003 . The measures of the age distribution at the county level are from Gardner and Cohen (1992). We used straight-line interpolations to create the values between 1930 and 1940. In fixed effects specifications, the coefficients of the demographic characteristics should be interpreted as the impact of city-specific trends for each characteristic.

We examined a variety of instruments in the first-stage relief equations relating to the political atmosphere in the cities or their states. The three instruments selected were the updated long-term volatility of the vote for president, representation on the House committee for Labor, and a Demcratic Governor dummy. The long-term presidential voting volatility was the standard deviation of the percent voting Democrat over the period from 1896 through the prior election, and we used voting information for the county in which the city was located from ICPSR file number 0001. For observations up to and including 1932, we calculated the standard deviation of Democratic voting using the election years from 1896 through 1928; for observations from years 1933 through 1936, the standard deviations are calculated from 1896 through 1932 election results; and for observations in years 1937 through 1940, the volatility 
measure uses election results from 1896 through 1936. We also explored using information on the percentage voting Democrat and the turnout in the most recent election from the same source. The variable measuring representation on the House labor committee for the county in which the city was located are from U.S. Congress (various years).

The Democratic governor variable is from Congressional Quarterly Inc. (1995, 639-63). There were three situations in which governors were from nontraditional parties. Minnesota Free-Labor party governors and Wisconsin Progressive party governors are treated as if they were Democrats in this comparison based on our reading of state histories of the 1930s. Oregon Independent governor Julius Meier is given a value of 0.5 because it appears that he was a centrist gubernatorial candidate. At the end of his term both parties sought to have him represent them in the next election.

We also explored the use of the party composition of the state legislatures and the timing of mayoral elections. The information on the percent Democrat in each state legislature comes from legislative manuals, state bluebooks, and House and Senate journals for each state from the collection housed at the Wisconsin State Historical Society. In many of the southern states the legislatures were overwhelmingly Democratic and many of the bluebooks did not bother to list party affiliations. To fill in any gaps we encountered, we used information from the New York Secretary of State, Manual, for the years 1925-1940. Information on gubernatorial election years is from the Congressional Quarterly Inc. (1995, 639-63), from the World Almanac and Book of Facts (1930, 313), and from searches on the internet when there were inconsistencies. To determine the timing of mayoral elections we used information on term lengths from the Municipal Yearbook in 1934 (Ridley and Nolting, 1934, 107-112) and matched it with information on the date the mayors' terms expired in the World Almanac and Book of Facts in tables entitled, "Mayors of American Cities" in the volumes spanning the years 1926 through 1940. When there were inconsistencies and discrepancies in the timing between the two sources, we searched for listings of mayors in the specific city on the internet and contacted libraries and officials in the city in question. If terms expired in January we assumed the election was in the preceding year. For terms expiring later than March we assumed the election was in the same year that the term expired. 
The death rates by specific causes through 1937 were reported in U.S. Department of Commerce, U.S. Bureau of the Census (1932, 1934, 1935a, 1935b, 1936a, 1936b, 1937, 1938, 1939). The published sources did not print city-specific information for 1938 through 1940. We aggregated the information on specific causes of death into larger categories based on the Preston, Keyfitz, and Schoen (1972) framework in the following ways: respiratory tuberculosis, suicides, and homicides are their own categories; other infectious and parasitic diseases include typhoid and paratyphoid fever, smallpox, measles, scarlet fever, whooping cough, diphtheria, erysipelas, epidemic cerebrospinal meningitis, tuberculosis of the meninges, other forms of tuberculosis, syphilis, poliomyelitis and polioencephalitis, and acute rheumatic fever; neoplasms include malaria, cancer, and other malignant tumors; cardiovascular disease includes cerebral hemorrhage and softening and diseases of the heart; influenza, bronchitis, pneumonia are combined into one category; diarrheal diseases include diarrhea and enteritis; certain degenerative diseases include rheumatism, diabetes mellitus, cirrhosis of the liver, nephritis, appendicitis and typhlitis, hernia, intestinal obstruction, chronic rheumatism, osteoarthritis, and gout; maternal mortality includes puerperal septicemia, and other puerperal causes; and motor vehicle accidents include automobile accidents and accident in collision with railroad trains and street cars. The specific death rates were reported only for cities and not for the counties.

The sources for the relief spending actually included 116 cities. We lacked critical information on key variables for Washington, DC. Further, Allentown, PA and Bethlehem, PA, which were reported separately in the relief data, were combined into one city-observation because of other data constraints. Information on infant mortality and births was not available for Texas cities and counties until 1932. Information on the Texas cities for causes of death were reported in the mortality statistics volumes (although not for the counties), so the Texas cities appear for the whole period in the panel for city-specific causes of death. Whenever we used the percent of state legislators that were Democrats, the following cities had missing information because Minnesota's legislature was non-partisan: Duluth, MN; Minneapolis, MN; and St. Paul. MN. When we controlled for pre-existing trends for 1921 through 1928, the sample of cities is reduced to 97 because some states were late in joining the registration areas. The 
cities eliminated are Kansas City and St. Louis in Missouri; Birmingham and Mobile in Alabama; New Orleans and Shreveport in Louisiana; Knoxville, Memphis, and Nashville in Tennessee; Atlanta, Georgia; Dallas, El Paso, Fort Worth, Houston, and San Antonio in Texas; Tulsa, Oklahoma, and Denver, Colorado. 


\section{FOOTNOTES}

${ }^{1}$ See, for example, Morris (1979) and OECD (2001).

${ }^{2}$ See Antonovsky and Bernstein (1977), Clifford and Brannon (1978), Waldmann (1992), and Haines (2000). For a more general discussion of how socioeconomic status of parents affects the treatment of children, see Paxson and Waldfogel (1999). For a discussion of how childhood health affects adulthood economic outcomes, see Case, Fertig, and Paxson (2003).

${ }^{3}$ For recent studies that have examined how modern social programs affect the status of children, see Conley and Springer (2001), Grossman and Jacobowitz (1981), Currie and Cole (1993), Haveman and Wolfe (1994), Currie and Thomas (1995a and 1995b), Currie and Gruber (1996a, 1996b, and 2001), Duncan and Brooks-Gunn (1997), Joyce (1999), and Blau (1999). Moreover, see Moffitt and Ver Ploeg (2001) for an extensive discussion of the current research underway examining the economic and social consequences of the 1996 Personal Responsibility and Work Opportunity Reconciliation Act that overhauled the modern welfare system.

${ }^{4}$ Inclusion of 1918 in the trend calculation has almost no effect on the general fertility rate trend, but makes the trends for both infant mortality and non-infant mortality even more negative than the trends in Figures 1 and 2. Thus, the inclusion of 1918 would make our claims that the Depression changed the trends even stronger.

${ }^{5}$ The discussion in this section focuses on the national aggregates. Estimates adjusted for changing registration areas over the period are very strongly correlated with the national estimates. The series for the national aggregates track closely with an aggregation of the 114-city sample. Correlations for the period 1930-1940 between the rates for our city sample and the national rate is .982 for the infant mortality rate, .966 for the non-infant death rate, and .954 for the general fertility rate. The infant mortality rate in the city sample is on average about 5.5 deaths per thousand live births lower than for the national rate. The general fertility rate in the city sample is on average about 19 births per 1000 women lower than for the national sample. 
${ }^{6}$ Given the downward trend in infant mortality rates prior to the $1930 \mathrm{~s}$, there remains the possibility that the negative relationship between the changes in infant mortality and the changes in relief spending are simply reflecting a pattern where cities that received an increase in relief spending in the 1930s were the ones experiencing steeper drops in infant mortality prior to 1933. We explore this issue more fully in the econometric analysis and find that it does not hold. In addition, we collected city-level infant mortality data for the period 1927 to 1929 , and then examined the correlation between the difference in average per capita relief from 1930-1932 to 1933-1940 and the difference in average infant mortality from 1927-1929 to 1930-1932. The correlation between the change in infant mortality between 1927-1929 and 1930-1932 and the change in relief spending between 1930-1932 and 1933-1940 is positive $(\rho=.165)$; therefore, we do not expect that pre-existing trends in infant mortality is imparting a spurious bias toward finding that changes in relief spending contributed to lower infant mortality during the 1930 s.

${ }^{7}$ For an empirical analysis of the FERA distribution, see Fishback, Kantor and Wallis (2003) and Fleck (1999c). For discussions of the administrative details of relief provision, see Brown (1940) and U.S. National Resources Planning Board (1942).

${ }^{8}$ Our relief measure includes some privately administered relief spending, which accounted for roughly one-quarter of relief spending prior to 1933, but less than one percent thereafter. Privately administered relief in many cases came from government sources. More detailed breakdowns for urban areas can be found in Baird (1942). Several programs that might be considered public assistance were not included in the reported relief data. For example, FERA emergency education, student aid, and transient programs were omitted. There is no information on the Civilian Conservation Corp, which provided employment in more isolated areas for many youths who came from urban areas. Spending on the National Youth Administration was omitted, as was the distribution of federal surplus commodities, which were bought from farmers as an agricultural relief measure. This form of relief did not account for a large share of aid in urban areas, but was important in rural areas. Also, information on earnings under the Public Works Administration was not included. But these projects tended to hire more skilled workers and, thus, the 
program's exclusion probably does not affect our conclusions regarding the effect of relief on the urban poor.

${ }^{9}$ For discussions of the FERA and CWA policies, see Brown (1940, 218-98) and U.S. National Resources Planning Board (1942, 26-97).

${ }^{10}$ We based this calculation on households reported in the IPUMS from 1940.

${ }^{11}$ The cities eliminated were generally western and southern cities and include Atlanta, Birmingham, Denver, El Paso, Fort Worth, Houston, Kansas City MO, Knoxville, Memphis, Mobile, Nashville, New Orleans, San Antonio, St. Louis, and Tulsa.

${ }^{12}$ In the 2SLS analysis of infant mortality rates the relief coefficient estimates without and with the predicted trend are -0.1185 and -0.1196 and the t-statistic changed by 0.02 . Similar results hold when we control for the general fertility rate and the noninfant death rate in the analysis. In analysis of the general fertility rate later in the paper, 90 of 97 cities displayed negative trends for 1921-1928, of which 81 were statistically significant. The OLS fixed effects coefficient for relief per capita changed from 0.0208 to 0.0207 and the t-statistics changed from 1.91 to 1.89 with the inclusion of the control for the prior trends; the 2SLS coefficient changed from 0.2523 to 0.2539 and the t-statistics changed from 3.97 to 3.99 . Similar small changes occurred when we added controls for the infant mortality rate and the non-infant death rate. The non-infant death rates generally displayed no trends in most cities for 1921 to 1928 with only 8 negative trends and 15 positive trends that were statistically significant at the 10 percent level out of 97 cities. Control for these prior trends in the fixed effects analysis for noninfant death rates changed the coefficients from -0.0014 to -0.0011 and the t-statistics from -0.92 to -0.73 . In the 2 SLS analysis the coefficient changed from -.0.0006 to -0.0036 and the t-statistics changed from -0.74 and -0.45 .

We also considered adding city-specific time trends. However, the correlates for the age distribution, ethnic percentages, and other census based variables are interpolated between census years using straight-line interpolations and thus would be perfectly collinear with a separate city-specific time trend. The coefficients on these census variables in the fixed effect specification are capturing the effect of 
the time trends for each of those variables within the city.

${ }^{14}$ In some cases matching rules were established in the original legislation but these were jettisoned soon after the distributions began (see Fishback, Kantor, and Wallis 2003 and sources cited there).

${ }^{15}$ We have explored the possibility of using several other instruments that have been proposed in other settings. For example, in his unemployment study, Robert Fleck (1999b) used both a measure of Democratic loyalty and a measure of voter turnout as instruments; therefore, we tried the percentage voting for the Democratic presidential candidate in the election prior to the year of the observation and the percentage turning out to vote in the prior presidential election (measured as a percentage of the 1930 population). We have also explored using the percentage of legislators that were Democrat in the upper house and lower house of the state legislatures. In studying modern crime, Steven Levitt (1997) has suggested the use of a dummy variable for election years as an instrument on the grounds that spending patterns might be influenced by the electoral cycle, but that the timing of elections, which are set by constitutions and charters, are unrelated to current socioeconomic phenomena. Therefore, we explored the use of gubernatorial and mayoral election years as potential identifying instruments. These additional instruments failed to meet one or more of our criteria for inclusion. In many cases when we added each potential instrument to the swing-voting, House labor committee, and Democratic governor instruments, the added instrument's coefficient in the first stage was either statistically insignificant or had an unexpected sign. The inclusion of the additional instruments produced estimates of the effect of relief on infant mortality and the various causes of death that are roughly comparable to the 2SLS results reported in the tables in the paper.

${ }^{16}$ As was the case for the fixed effects estimates, inclusion of the 1921-1928 trend in the 2SLS analysis with fixed effects had virtually no impact on the relief coefficient and the coefficient on the prior trend prediction was statistically insignificant.

${ }^{17}$ To the extent that families were seeking a target family size, higher death rates among infants might have led to increased fertility rates. This same link may exist between the non-infant mortality and fertility rates. 
There is evidence from other sources that about .6 to .8 of each child death was replaced in the United States around 1910. Only about .25 of this effect can be attributed to direct replacement, however, the rest seems to have been precautionary "hoarding" by parents trying to avoid the risk of having too few surviving children (Haines 1998, Table 7.6). There might be some replacement effect associated with the non-infant death rate, but most childhood deaths occurred in infancy. The proportion of all deaths below age 5 that occurred between the ages of 1 and 4 was 24.4 percent in 1932 and 17.8 percent in 1940. The proportion of deaths for children aged 1 to 4 relative to all non-infant deaths was 3.9 percent in 1930 and 1.8 percent in 1940 .

${ }^{18}$ Preston $(1976,106)$ points out that 80 to 90 percent of the variance in the death rate of any particular age group can be "explained" by the variation in the death rate among all age groups. In other words, if there were an unusual surge in non-infant deaths, infants deaths would follow suit.

${ }^{19}$ In these analyses the infant mortality rate was positively related to the non-infant death rate, while the general fertility rate is positively related to infant mortality in some specifications and tends to be statistically insignificant and negative in others. Results are available from the authors.

${ }^{20}$ See Brainerd (2001) and Ruhm (2000) and Cutler, Glaeser and Norberg (2000) for the impact of income on suicides. Fajnzylber, Lederman, and Loayza (2002a and 2002b) find that improvements in economic growth reduce homicides. Ruhm (2000), on the other hand, finds that homicides in the U.S. are procyclical in the 1970s and 1980s.

${ }^{21}$ Fajnzylber, Lederman, and Loayza (2002a and 2002b), Kennedy, Kawachi, and Prothrow Stith (1996), Kaplan, et. al. (1996), and Potter (1991) find that reductions in poverty reduce homicides.

${ }^{22}$ Table 5 shows no strong positive relationship between infant mortality and retail sales. However, Dehejia and Lleras-Muney (2004) find a selection effect with modern data that shows better health of babies during periods of high unemployment.

${ }^{23}$ Market values of life are from Moore and Viscusi $(1990,14)$ with adjustments to year 2000 values using the GDP Deflator (Council of Economic Advisors 2001, 282). 
${ }^{24}$ For example, the number of marriages declined from $1,233,000$ in 1929 to 982,000 in 1932 . The number of live births declined from 2,618,000 in 1930 to 2,307,000 in 1933 (U.S. Bureau of the Census, 1975, Series B 1-4).

${ }^{25}$ Over the course of the 1930 s, the population-weighted average infant mortality rate in the city sample fell by 20.4 per thousand, from 59.8 in 1930 to 39.4 in 1940 . During the same period per capita relief spending rose by approximately $\$ 49.19$, from $\$ 3.74$ in 1930 to $\$ 52.93$ in 1940 (in constant 1967 dollars). Based on the 2SLS with fixed effects coefficient of -0.163 , this increase in relief spending was associated with a reduction of 8 infant deaths per thousand live births. Given the 20.4 decline in average infant mortality rates in the sample cities over the decade, the rise in relief spending can account for roughly 39 percent of the decline in infant mortality in the 1930s. 


\section{REFERENCES}

Antonovsky, Aaron, and Judith Bernstein, "Social Class and Infant Mortality," Social Science and Medicine 11 (May 1977), 453-70.

Baird, Enid, Public and Private Aid in 116 Urban Areas, 1929-38, with Supplement for 1939 and 1940, U.S. Federal Security Agency, Social Security Board, Public Assistance Report No. 3 (Washington, DC: Government Printing Office, 1942).

Blank, Rebecca, "Teen Pregnancy: Government Programs Are Not the Cause," Feminist Economics 1 (Summer 1995), 47-58.Blau, David M., "The Effect of Income on Child Development," Review of Economics and Statistics 81 (May 1999), 261-76.

Brainerd, Elizabeth. "Economic Reform and Mortality in the Former Soviet Union: A Study of the Suicide Epidemic in the 1990s." European Economic Review 45 (2001): 1007-1019.

Brown, Josephine C., Public Relief, 1929-1939 (New York: Henry Holt and Company, 1940).

Case, Anne, Angela Fertig, and Christina Paxson, "From Cradle to Grave? The Lasting Impact of Childhood Health and Circumstance," National Bureau of Economic Research working paper 9788 (June 2003).

Clifford, William B., and Yevonne S. Brannon, "Socioeconomic Differentials in Infant Mortality: An Analysis Over Time," Public Use Data 6 (Jan. 1978), 29-37.

Congressional Quarterly Inc., Guide to U.S. Elections, third edition (Washington, DC: Congressional Quarterly Inc., 1995).

Conley, Dalton1 and Kristen Springer, "Welfare State and Infant Mortality." American Journal of Sociology 107 (November 2001): 768-807.

Couch, Jim, and William Shughart, The Political Economy of the New Deal (New York: Edward Elgar, 1998).

Council of Economic Advisors, Economic Report of the President, January 2001 (Washington, DC: Government Printing Office, 2001).

Currie, Janet, and Nancy Cole, "Welfare and Child Health: The Link between AFDC Participation and Birth Weight," American Economic Review 83 (Sept. 1993), 971-85.

Currie, Janet, and Jonathan Gruber, "Health Insurance Eligibility, Utilization of Medical Care, and Child Health," Quarterly Journal of Economics 11 (May 1996a), 431-66.

"Saving Babies: The Efficacy and Cost of Recent Changes in the Medicaid Eligibility of Pregnant Women," Journal of Political Economy 104 (Dec. 1996b), 1263-96.

"Public Health Insurance and Medical Treatment: The Equalizing Impact of Medicaid Expansions," Journal of Public Economics 82 (Oct. 2001), 63-89.

Currie, Janet, and Duncan Thomas, "Does Head Start Make a Difference?” American Economic Review 85 (June 1995a), 341-64.

, "Medical Care for Children: Public Insurance, Private Insurance, and Racial Differences in Utilization," Journal of Human Resources 30 (Winter 1995b), 135-62.

Cutler, David M., and Ellen Meara, "Changes in the Age Distribution of Mortality Over the $20^{\text {th }}$ Century," National Bureau of Economic Research Working Paper 8556, October 2001.

Cutler, David, Edward and Karen Norberg. "Explaining the Rise in Youth Suicide." National Bureau of Economics Research Working Paper Number 7713 (2000).

Dehejia, Rajeev and Adraina Lleras Muney. "Booms, Busts, and Babies' Health." The Quarterly Journal of Economics 119: 1091-1130.

Duncan, Greg J., and Jeanne Brooks-Gunn, eds., Consequences of Growing Up Poor (New York: Russell Sage Foundation, 1997).

Eckberg, Douglas Lee. "Estimates of Early Twentieth-Century U.S. Homiced Rates: An Econometric Forecasting Approach.” Demography 32 (February 1995): 1-16.

Fajnzylber, Pablo, Daniel Lederman, and Norman Loayza. "Inequality and Violent Crime?" Journal of Law and Economics 45 (April 2002a): 1-40. 
Fajnzylber, Pablo, Daniel Lederman, and Norman Loayza. "What Causes Violent Crime?" European Economic Review 46 (2002b): 1323-1357.

Federal Emergency Relief Administration. Unemployment Relief Census, October 1933, Report Number One (Washington, DC: Government Printing Office, 1934).

Fishback, Price V., Michael R. Haines, and Shawn Kantor, "The Impact of New Deal Programs on Black and White Infant Mortality in the South," Explorations in Economic History 38 (Jan. 2001), 93122.

Fishback, Price V., William C. Horrace, and Shawn Kantor, "Federal Programs in Times of Crisis: The Impact of the New Deal on Local Economies during the Great Depression," National Bureau of Economic Research working paper 8108 (revised June 2003).

Fishback, Price V., Shawn Kantor, and John Joseph Wallis. "Can the New Deal's Three R's Be Rehabilitated? A Program-by-Program, County-by-County Analysis," Explorations in Economic History 40 (July 2003), 278-307.

Fleck, Robert K., "Electoral Incentives, Public Policy, and the New Deal Realignment,” Southern Economic Journal 63 (Jan. 1999a), 377-404.

"Inter-party competition, intra-party competition, and distributive Policy: A Model and Test using New Deal Data," Public Choice 108 (July 2001a), 77-100.

, "The Marginal Effect of New Deal Relief Work on County-Level Unemployment Statistics," Journal of Economic History 59 (September 1999b), 659-87.

, "Population, Land, Economic Conditions, and the Allocation of New Deal Spending,"Explorations in Economic History 38 (April 2001b), 296-304.

,"The Value of the Vote: A Model and Test of the Effects of Turnout on Distributive Policy," Economic Inquiry 37 (October 1999c), 609-23.

Gardner, John, and William Cohen, Demographic Characteristics of the Population of the United States, 1930-1950: County Level, Inter-university Consortium for Political and Social Research, file number 0020, 1992.

Greene, William H., Econometric Analysis, fifth edition (Upper Saddle River, NJ: Prentice Hall, 2003).

Grogger, Jeff and Stephen G. Bronars. "The Effect of Welfare Payments on the Marriage and Fertility Behavior of Unwed Mothers: Results from a Twins Experiment." Journal of Political Economy 109 (2001): 529-545.

Grossman, Michael, and Steven Jacobowitz, "Variations in Infant Mortality Rates Among Counties of the United States: The Roles of Public Policies and Programs," Demography 18 (Nov. 1981), 695713.

Haines, Michael R., "The Population of the United States, 1790-1920," in Stanley Engerman and Robert Gallman, eds., The Cambridge Economic History of the United States, Volume II (New York: Cambridge University Press, 2000), chapter 4.

, "The Relationship between Infant and Child Mortality and Fertility: Some Historical and Contemporary Evidence for the United States," in Mark R. Montgomery and Barney Cohen, eds., From Death to Birth: Mortality Decline and Reproductive Change (Washington, DC: National Academy Press, 1998), 227-53.

Hausman, Jerry A., "Specification and Estimation of Simultaneous Equations Models," in Zvi Griliches and Michael D. Intriligator, eds., Handbook of Econometrics (Amsterdam: North Holland, 1983).

Haveman, Robert H., and Barbara S. Wolfe, Succeeding Generations: On the Effects of Investments in Children (New York: Russell Sage Foundation, 1994).

Howard, Donald S., The WPA and Federal Relief Policy (New York: Russell Sage Foundation, 1943). Inter-University Consortium for Political and Social Research, Historical, Demographic, Economic, and Social Data: The United States, 1790-1970, file number 0003. The version has additions and corrections by Michael Haines, Department of Economics, Colgate University, Hamilton, NY. , United States Historical Election Returns, 1824-1968, file number 0001. 
Jensen, Robert and Kaspar Richter. "Understanding the Relationship Between Poverty and Children's Health.” European Economic Review 45 (2001): 1031-1039.

Joyce, Theodore, "Impact of Augmented Prenatal Care on Birth Outcomes of Medicaid Recipients in New York City," Journal of Health Economics 18 (Jan. 1999), 31-67.

Kaplan, George, Elsie Pamuk, John Lynch, Richard Cohen, and Jennifer Balfour. "Inequality in Income and Mortality in the United States: Analysis of Mortality and Potential Pathways." British Medical Journal 312 (April 1996): 999-1003.

Kennedy, Bruce P., Ichiro Kawachi, and Deborah Prothrow-Stith. "Income Distribution and Mortality: Cross Sectional Ecological Study of the Robin Hood Index in the United States." British Medical Journal 312 (April 1996): 1004-1007.

Kousser, J. Morgan, The Shaping of Southern Politics: Suffrage Restriction and the Establishment of the One-Party South, 1880-1910 (New Haven, CT: Yale University Press, 1974).

Levitt, Steven D., "Using Electoral Cycles in Police Hiring to Estimate the Effect of Police on Crime," American Economic Review 87 (June 1997), 270-90.

Lijphart, Arend, “Unequal Participation: Democracy's Unresolved Dilemma," American Political Science Review 91 (March 1997), pp. 1-14.

McCann, Carole R. Birth Control Politics in the United States, 1916-1945. Ithaca, New York: Cornell University Press, 1994.

McKeown, Thomas. The Rise of Population. London : Edward Arnold, 1976.

Meller, Jennifer. "The Effect of Family Planning Programs on the Fertility of Welfare Recipients:

Evidence from Medicaid Claims.” Journal of Human Resources 33 (Autumn 1998): 866-896.

Moffitt, Robert A., and Michele Ver Ploeg, Evaluating Welfare Reform in an Era of Transition

(Washington, DC: National Academy Press, 2001)

Moore, Michael J., and W. Kip Viscusi, Compensation Mechanisms for Job Risk: Wages, Workers' Compensation and Product Liability (Princeton, NJ: Princeton University Press, 1990).

Morris, Morris David, Measuring the Condition of the World's Poor: The Physical Quality of Life Index (New York: Pergamon Press, 1979).

New York Secretary of State, Manual, various years, 1925-1940.

Organization for Economic Cooperation and Development (OECD), Society at a Glance: OECD Social Indicators (Washington, DC: OECD, 2001).

Paxson, Christina, and Jane Waldfogel, "Parental Resources and Child Abuse and Neglect," American Economic Review, Papers and Proceedings 89 (May 1999), 239-44.

Potter, Lloyd B. "Socioeconomic Determinants of White and Black Males' Life Expectancy Differentials, 1980.” Demography 28 (May 1991): 303-321.

Preston, Samuel H., Mortality Patterns in National Populations with Special Reference to Recorded Causes of Death (New York: Academic Press, 1976).

Preston, Samuel; Nathan Keyfitz, and Robert Schoen. Causes of Death: Life Tables for National Population. New York: Seminar Press, 1972.

Ridley, Clarence E., and Orin F. Nolting, The Municipal Year Book, 1934 (Chicago: International City Managers' Association, 1934).

Rogers, Richard, Rebecca Rosenblatt, Robert Hummer, and Patrick Krueger. "Black-White Differentials in Adult Homicide Mortality in the United States." Social Science Quarterly 82 (September 2001): 435-452.

Ruhm, Christopher. “Are Recessions Good for Your Health?” Quarterly Journal of Economics 115 (May 2000): 617-650.

Schultz, T. Paul. "Marital Status and Fertility in the United States." Journal of Human Resources 29 (Spring 1994): 637-669.

Skocpol, Theda, Protecting Soldiers and Mothers: The Political Origins of Social Policy in the United States (Cambridge, MA: Belknap Press 1992).

Troesken, Werner, Water, Race, and Disease. Cambridge, Massachusetts, MIT Press, 2004. 
U.S. Bureau of the Census, Birth Statistics for the Birth Registration Area of the United States, 1921, Seventh Annual Report (Washington, DC: Government Printing Office, 1923).

U.S. Bureau of the Census, Birth Stillbirth, and Infant Mortality Statistics for the Birth Registration Area of the United States, 1922, Eighth Annual Report (Washington, DC: Government Printing Office, 1924).

U.S. Bureau of the Census, Birth Stillbirth, and Infant Mortality Statistics for the Birth Registration Area of the United States, 1923, Ninth Annual Report (Washington, DC: Government Printing Office, 1925).

U.S. Bureau of the Census, Birth Stillbirth, and Infant Mortality Statistics for the Birth Registration Area of the United States, 1924, Tenth Annual Report (Washington, DC: Government Printing Office, 1926).

U.S. Bureau of the Census, Birth Stillbirth, and Infant Mortality Statistics for the Birth Registration Area of the United States, 1925, Eleventh Annual Report (Washington, DC: Government Printing Office, 1927).

U.S. Bureau of the Census, Birth Stillbirth, and Infant Mortality Statistics for the Birth Registration Area of the United States, 1926, Twelfth Annual Report (Washington, DC: Government Printing Office, 1929).

U.S. Bureau of the Census, Birth Stillbirth, and Infant Mortality Statistics for the Birth Registration Area of the United States, 1927, Thirteenth Annual Report (Washington, DC: Government Printing Office, 1930a).

U.S. Bureau of the Census, Birth Stillbirth, and Infant Mortality Statistics for the Birth Registration Area of the United States, 1928, Fourteenth Annual Report (Washington, DC: Government Printing Office, 1930b).

U.S. Bureau of the Census, Birth Stillbirth, and Infant Mortality Statistics for the Birth Registration Area of the United States, 1929, Fifteenth Annual Report (Washington, DC: Government Printing Office, 1932).

U.S. Bureau of the Census, Birth Stillbirth, and Infant Mortality Statistics for the Birth Registration Area of the United States, 1930, Sixteenth Annual Report (Washington, DC: Government Printing Office, 1934a).

U.S. Bureau of the Census, Birth Stillbirth, and Infant Mortality Statistics for the Birth Registration Area of the United States, 1931, Seventeenth Annual Report (Washington, DC: Government Printing Office, 1934b).

U.S. Bureau of the Census, Birth Stillbirth, and Infant Mortality Statistics for the Birth Registration Area of the United States, 1932, Eighteenth Annual Report (Washington, DC: Government Printing Office, 1934c).

U.S. Bureau of the Census, Birth Stillbirth, and Infant Mortality Statistics for the Continental United States, The Territory of Hawaii, and the Virgin Islands, 1933, Nineteenth Annual Report (Washington, DC: Government Printing Office, 1936a).

U.S. Bureau of the Census, Birth Stillbirth, and Infant Mortality Statistics for the Continental United States, The Territory of Hawaii, and the Virgin Islands, 1934, Twentieth Annual Report (Washington, DC: Government Printing Office, 1936b).

U.S. Bureau of the Census, Birth Stillbirth, and Infant Mortality Statistics for the Continental United States, The Territory of Hawaii, and the Virgin Islands, 1935, Twenty-First Annual Report (Washington, DC: Government Printing Office, 1937).

U.S. Bureau of the Census, Birth Stillbirth, and Infant Mortality Statistics for the Continental United States, The Territory of Hawaii, and the Virgin Islands, 1936, Twenty-Second Annual Report (Washington, DC: Government Printing Office, 1938).

U.S. Bureau of the Census, Birth Stillbirth, and Infant Mortality Statistics for the Continental United States, The Territory of Hawaii, and the Virgin Islands, 1937, Twenty-Third Annual Report (Washington, DC: Government Printing Office, 1939). 
U.S. Bureau of the Census, Birth Stillbirth, and Infant Mortality Statistics for the Continental United States, The Territory of Hawaii, and the Virgin Islands, 1938, Twenty-Fourth Annual Report (Washington, DC: Government Printing Office, 1940).

U.S. Bureau of the Census, Birth Stillbirth, and Infant Mortality Statistics for the Continental United States, The Territory of Hawaii, and the Virgin Islands, 1939, Twenty-Fifth Annual Report (Washington, DC: Government Printing Office, 1941).

U.S. Bureau of the Census, Birth Stillbirth, and Infant Mortality Statistics for the Continental United States, The Territory of Hawaii, and the Virgin Islands, 1940, Twenty-Sixth Annual Report (Washington, DC: Government Printing Office, 1942).

U.S. Bureau of Census, Historical Statistics of the United States: Colonial Times to 1970 (Washington, DC: Government Printing Office , 1975).

U.S. Department of Commerce, U.S. Bureau of the Census, Mortality Statistics, 1929, Thirtieth Annual Report, (Washington, DC: Government Printing Office, 1932).

U.S. Department of Commerce, U.S. Bureau of the Census, Mortality Statistics, 1930, Thirty-First Annual Report, (Washington, DC: Government Printing Office, 1934).

U.S. Department of Commerce, U.S. Bureau of the Census, Mortality Statistics, 1931, Thirty-Second Annual Report, (Washington, DC: Government Printing Office, 1935a).

U.S. Department of Commerce, U.S. Bureau of the Census, Mortality Statistics, 1932, Thirty-Third Annual Report, (Washington, DC: Government Printing Office, 1935b).

U.S. Department of Commerce, U.S. Bureau of the Census, Mortality Statistics, 1933, Thirty-Fourth Annual Report, (Washington, DC: Government Printing Office, 1936a).

U.S. Department of Commerce, U.S. Bureau of the Census, Mortality Statistics, 1934, Thirty-Fifth Annual Report, (Washington, DC: Government Printing Office, 1936b).

U.S. Department of Commerce, U.S. Bureau of the Census, Mortality Statistics, 1935, Thirty-Sixth Annual Report, (Washington, DC: Government Printing Office, 1937).

U.S. Department of Commerce, U.S. Bureau of the Census, Mortality Statistics, 1936, Thirty-Seventh Annual Report, (Washington, DC: Government Printing Office, 1938).

U.S. Department of Commerce, U.S. Bureau of the Census, Vital Statistics of the United States, 1937, Part 1. (Washington, DC: Government Printing Office, 1939).

U. S. Bureau of Economic Analysis, State Personal Income: 1929-1987 (Washington, DC: Government Printing Office, 1989).

U.S. Bureau of Labor Statistics, "Public Provision for Pensions for the Blind in 1934,” Monthly Labor Review 41 (Sept. 1935), 584-601.

U.S. Committee on Economic Security, Social Security in America: The Factual Background of the Social Security Act as Summarized from Staff Reports to the Committee on Economic Security (Washington, DC: Government Printing Office, 1937).

U.S. Congress, Official Congressional Directory, $73^{\text {rd }}$ Congress $1^{\text {st }}$ session through $76^{\text {th }}$ Congress (Washington, DC: Government Printing Office, various years).

U.S. Department of Commerce, Bureau of Foreign and Domestic Commerce, Consumer Market Data Handbook, 1936 (Washington, DC: Government Printing Office, 1936)

U.S. Department of Commerce, Bureau of Foreign and Domestic Commerce, Consumer Market Data Handbook, 1939. (Washington, DC: Government Printing Office, 1939).

U.S. National Resources Planning Board, Security, Work, and Relief Policies (Washington, DC: Government Printing Office, 1942).

Waldmann, Robert J., "Income Distribution and Infant Mortality," Quarterly Journal of Economics 107 (Nov. 1992), 1284-302.

Wallis, John Joseph. "The Political Economy of New Deal Spending Revisited, Again: With and Without Nevada," Explorations in Economic History 35 (April 1998), 140-70.

"The political economy of New Deal spending, yet again: A reply," Explorations in Economic History 38 (April 2001), 305-14. 
Winslow, Emma A., Trends in Different Types of Public and Private Relief in Urban Areas, 1929-35, U.S. Department of Labor, Children's Bureau Publication No. 237 (Washington, DC: Government Printing Office, 1937).

World Almanac and Book of Facts (New York: New York World and New York World-Telegram, various years).

Wright, Gavin, "The Political Economy of New Deal Spending: An Econometric Analysis," Review of Economics and Statistics 56 (Feb. 1974), 30-38. 
Table 1

Trends in Vital Statistics and Relief Spending in Major Cities, 1930 to 1940

\begin{tabular}{rrrrrrr}
\hline Year & $\begin{array}{c}\text { Infant } \\
\text { mortality } \\
\text { rate }\end{array}$ & $\begin{array}{c}\text { Non- } \\
\text { infant } \\
\text { death } \\
\text { rate }\end{array}$ & $\begin{array}{c}\text { General } \\
\text { fertility } \\
\text { rate }\end{array}$ & $\begin{array}{c}\text { Per } \\
\text { capita } \\
\text { relief } \\
\text { spending } \\
\mathbf{( 1 9 6 7 ~ \$ )}\end{array}$ & $\begin{array}{c}\text { Average } \\
\text { annual relief } \\
\text { benefits as a } \\
\text { percentage of } \\
\text { annual } \\
\text { manufacturing } \\
\text { earnings }\end{array}$ & $\begin{array}{c}\text { Federal } \\
\text { share of } \\
\text { relief } \\
\text { spending }\end{array}$ \\
\hline 1930 & 59.6 & 11.4 & 69.3 & $\$ 3.74$ & & \\
1931 & 58.7 & 11.3 & 64.3 & 9.06 & & \\
1932 & 53.1 & 11.1 & 61.1 & 18.06 & & \\
1933 & 52.2 & 11.0 & 56.7 & 29.71 & $21.7 \%$ & 51.8 \\
1934 & 52.9 & 11.2 & 57.4 & 47.93 & 31.2 & 78.9 \\
1935 & 49.8 & 11.2 & 57.3 & 51.03 & 33.3 & 78.9 \\
1936 & 49.6 & 11.7 & 56.8 & 61.78 & 42.4 & 74.7 \\
1937 & 46.5 & 11.6 & 58.6 & 52.24 & 37.6 & 72.1 \\
1938 & 42.3 & 10.9 & 60.5 & 69.61 & 39.3 & 62.0 \\
1939 & 40.6 & 11.0 & 59.7 & 63.32 & 38.3 & 62.5 \\
1940 & 39.2 & 11.2 & 62.8 & 52.93 & 34.9 & 57.4 \\
\hline
\end{tabular}

Notes: The demographic variables are weighted by the populations of the counties in which the 114 sample cities are located. For 1930 to 1932, the averages do not include information for the Texas cities in the sample because such data were not available. The infant mortality rate is the number of deaths of children under age one per thousand live births in each year. The general fertility rate is the number of births in each year per thousand women aged 15 to 44 . The number of women aged 15 to 44 for the years 1931 through 1939 were determined by straight-line interpolations between the decennial censuses. The non-infant death rate is the number of deaths of people aged 1 year and older each year per 1,000 population. The populations for 1931 through 1939 were determined by straight-line interpolations between 1930 and 1940.

The relief per capita measure is the total of all direct relief, work relief and private relief funds. Direct relief includes direct relief under the FERA, by state and local governments, and categorical assistance for dependent children, old-age assistance, and aid to the blind. Prior to 1935 the categorical assistance categories refer to funds provided by state and local governments through mothers' pensions, old-age pensions, and state aid to the blind. Work relief includes payments to workers on state and local government, FERA, CWA, and WPA projects. Private relief is the value of relief funds from private and public sources administered by private agencies.

Average annual relief benefits were calculated as the ratio of total relief expenditures per number of households on relief. The data source reported the information monthly and we summed across months for the annual estimate. The 1940 data were only reported through June, so we doubled the amount reported to derive the annual estimate.

We do not have information on the federal share of relief prior to 1932, but it was probably similar to 1932's value. The federal share of relief information includes the cost of administering the programs. The 1932 federal figure includes $\$ 3.7$ million in federal workers' compensation payments. The state and local expenditures include workers' compensation, general relief, old-age assistance, aid to dependent children, aid to the blind, and state shares of unemployment compensation, WPA, CWA, and the National Youth Administration. 
Sources: For per capita relief and the demographic rates, see the Data Appendix. For federal share of relief spending, see U.S. National Resources Planning Board (1942, 292, 598-603). Average relief expenditures per household were calculated from data on households receiving relief and total expenditures on relief in U.S. National Resources Planning Board (1942, 557-61). Average annual manufacturing earnings are from U.S. Bureau of the Census Bureau $(1975,166)$. 
Table 2

Impact of Relief Spending Per Capita on Infant Mortality Rate, 1929-1940

Specification

Specifications without Non-infant Death Rate

and General Fertility Rate

OLS with no correlates and no fixed effects

OLS with correlates without fixed effects

OLS with correlates and fixed effects

Full Sample

Subsample for comparison with 1921-28

trend

Subsample with 1921-28 trend included

2SLS with correlates and fixed effects

Full Sample

Subsample for comparison with 1921-28

trend

Subsample with 1921-28 trend included

Specifications Including Non-infant Death Rate

and General Fertility Rates

OLS with no correlates and no fixed effect

OLS with correlates without fixed effects

OLS with correlates and fixed effects

Full Sample

Subsample for comparison with 1921-28

trend

Subsample with 1921-28 trend included

2SLS with correlates and fixed effects

Full Sample

Subsample for comparison with 1921-28

trend

Subsample with 1921-28 trend included $\begin{array}{llc}\begin{array}{l}\text { Relief } \\ \text { Coeff. }\end{array} & \text { t-stat. } & \text { OSD }^{1} \\ \text { Effect }^{1}\end{array}$

$\begin{array}{lll}-0.3208 & -23.91 & -0.526\end{array}$

$\begin{array}{lll}-0.2698 & -19.87 & -0.442\end{array}$

$\begin{array}{lll}-0.0319 & -1.78 & -0.052\end{array}$

$\begin{array}{lll}-0.0368 & -2.05 & -0.060\end{array}$

$\begin{array}{lll}-0.0358 & -2.01 & -0.059\end{array}$

$\begin{array}{lll}-0.1628 & -1.82 & -0.267\end{array}$

$\begin{array}{lll}-0.1141 & -1.44 & -0.187\end{array}$

$\begin{array}{lll}-0.1146 & -1.45 & -0.188\end{array}$

$\begin{array}{lll}-0.2827 & -24.26 & -0.463 \\ -0.2481 & -20.18 & -0.406\end{array}$

$\begin{array}{lll}-0.2481 & -20.18 & -0.406\end{array}$

$\begin{array}{lll}-0.0348 & -2.18 & -0.057 \\ -0.0438 & -2.74 & -0.072 \\ & & \\ -0.0418 & -2.64 & -0.069\end{array}$

$\begin{array}{lll}-0.1699 & -2.12 & -0.278\end{array}$

$\begin{array}{lll}-0.1299 & -1.82 & -0.213\end{array}$

$\begin{array}{lll}-0.1297 & -1.82 & -0.213\end{array}$

Notes. The correlates are listed in Table 3. The t-statistics are based on robust White-corrrected standard errors. In all 2SLS specifications, the identifying instruments in the first stage have coefficients that are statistically significant at the 10 percent level individually. The t-statistics on the swing measure range 
from 3.30 to 5.20, on the house labor committee measures from 1.80 to 2.05, and on the Democratic governor measure from 4.97 to 5.63. The F-statistics for the identifying instruments as a group are all 16.8 or higher. The results of Hausman over-identification tests in all cases are consistent with the hypothesis that the identifying instruments have not been inappropriately omitted from the final stage equation.

${ }^{1}$ The OSD effect is the number of standard deviations by which the infant mortality rate is changed with a one-standard-deviation increase in relief spending per capita. 
Table 3

Estimation Results, 1929-1940: OLS, OLS with City and Year Fixed Effects, 2SLS with City and Year Fixed Effects

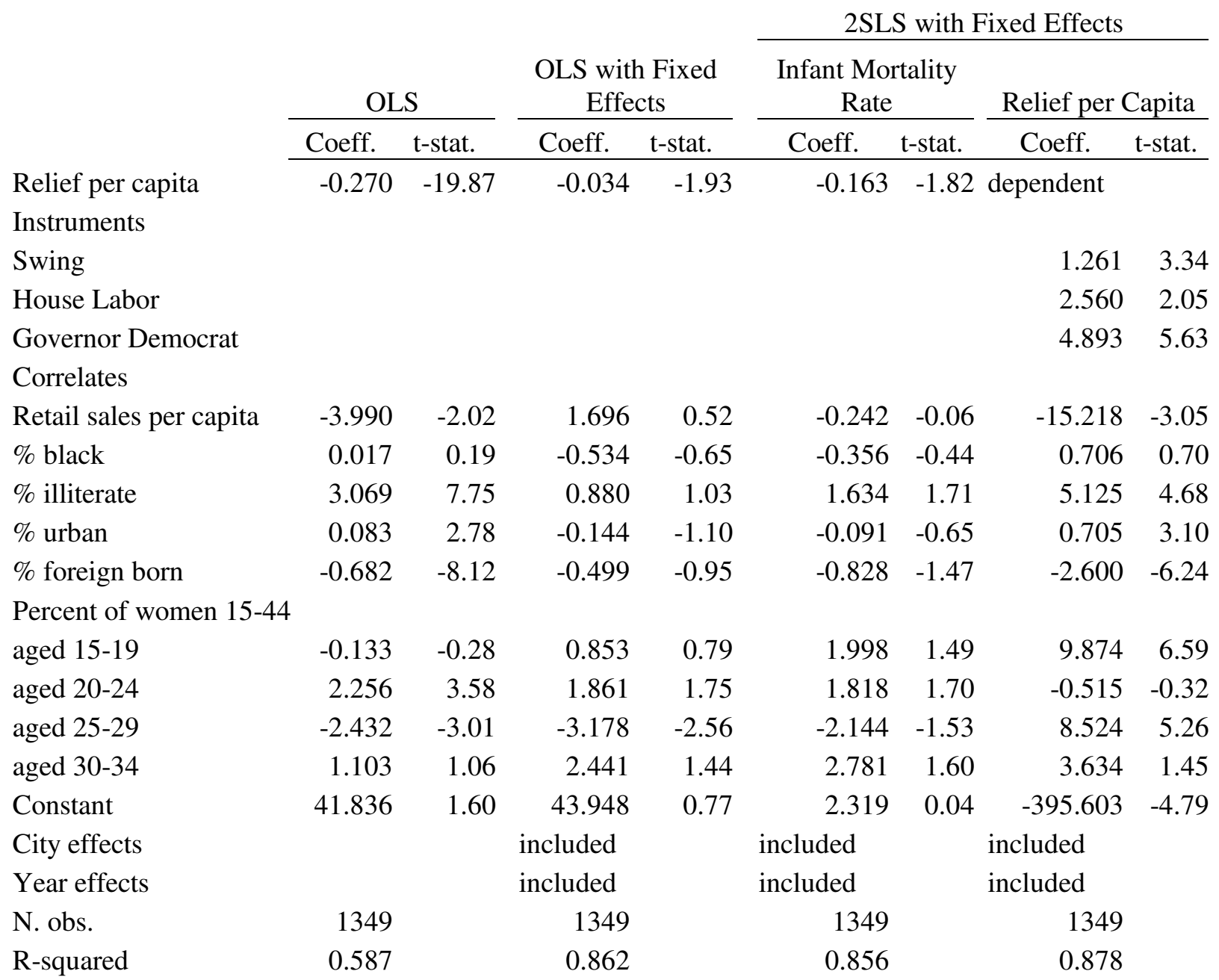

The t-statistics are based on White-corrected robust standard errors. 
Table 4

Impact of Relief Spending per Capita on General Fertility Rates and Non-infant Death Rate, 19291940 and Rates for Specific Causes of Death, 1929-1937.

\begin{tabular}{|c|c|c|c|c|c|}
\hline Rate & & OLS & $\begin{array}{l}\text { OLS with } \\
\text { Correlates }\end{array}$ & $\begin{array}{l}\text { OLS with } \\
\text { Correlates } \\
\text { and Fixed } \\
\text { Effects }\end{array}$ & $\begin{array}{l}\text { 2SLS with } \\
\text { Fixed Effects }\end{array}$ \\
\hline $\begin{array}{l}\text { Noninfant Death } \\
\text { Rate }\end{array}$ & $\begin{array}{l}\text { OSD Effect } \\
\text { t-statistic }\end{array}$ & $\begin{array}{l}-0.116 \\
(-4.36)\end{array}$ & $\begin{array}{l}-0.087 \\
(-3.11)\end{array}$ & $\begin{array}{l}-0.026 \\
(-1.42)\end{array}$ & $\begin{array}{l}-0.099 \\
(-0.99)\end{array}$ \\
\hline $\begin{array}{l}\text { Noninfant Death } \\
\text { Rate controlling } \\
\text { for GFR and IMR }\end{array}$ & $\begin{array}{l}\text { OSD Effect } \\
\text { t-statistic }\end{array}$ & $\begin{array}{l}0.178 \\
(6.59)\end{array}$ & $\begin{array}{l}-0.019 \\
(-0.79)\end{array}$ & $\begin{array}{r}-0.001 \\
(-0.1)\end{array}$ & $\begin{array}{l}-0.271 \\
(-1.47)\end{array}$ \\
\hline Homicides & $\begin{array}{l}\text { OSD Effect } \\
\text { t-statistic }\end{array}$ & $\begin{array}{r}-0.317 \\
(-13.73)\end{array}$ & $\begin{array}{l}-0.119 \\
(-5.25)\end{array}$ & $\begin{array}{l}-0.032) \\
(-1.42)\end{array}$ & $\begin{array}{l}-0.211 \\
(-1.58)\end{array}$ \\
\hline Suicides & $\begin{array}{l}\text { OSD Effect } \\
\text { t-statistic }\end{array}$ & $\begin{array}{r}-0.148 \\
(-4.9)\end{array}$ & $\begin{array}{l}-0.323 \\
(-8.55)\end{array}$ & $\begin{array}{l}-0.123 \\
(-2.14)\end{array}$ & $\begin{array}{l}-0.853 \\
(-2.51)\end{array}$ \\
\hline $\begin{array}{l}\text { Respiratory } \\
\text { Tuberculosis }\end{array}$ & $\begin{array}{l}\text { OSD Effect } \\
\text { t-statistic }\end{array}$ & $\begin{array}{l}-0.273 \\
(-9.55)\end{array}$ & $\begin{array}{l}-0.057 \\
(-1.75)\end{array}$ & $\begin{array}{l}0.010 \\
(0.41)\end{array}$ & $\begin{array}{l}0.154 \\
(1.01)\end{array}$ \\
\hline $\begin{array}{l}\text { Infectious and } \\
\text { Parasitic Diseases }\end{array}$ & $\begin{array}{l}\text { OSD Effect } \\
\text { t-statistic }\end{array}$ & $\begin{array}{r}-0.339 \\
(-13.67)\end{array}$ & $\begin{array}{r}-0.037 \\
(-1.3)\end{array}$ & $\begin{array}{l}0.117 \\
(2.21)\end{array}$ & $\begin{array}{l}-0.576 \\
(-2.24)\end{array}$ \\
\hline Neoplasms & $\begin{array}{l}\text { OSD Effect } \\
\text { t-statistic }\end{array}$ & $\begin{array}{l}0.369 \\
(13.2)\end{array}$ & $\begin{array}{r}0.113 \\
(3.4)\end{array}$ & $\begin{array}{l}0.051 \\
(1.51)\end{array}$ & $\begin{array}{l}0.265 \\
(1.47)\end{array}$ \\
\hline $\begin{array}{l}\text { Cardiovascular } \\
\text { Disease }\end{array}$ & $\begin{array}{l}\text { OSD Effect } \\
\text { t-statistic }\end{array}$ & $\begin{array}{r}0.364 \\
(12.42)\end{array}$ & $\begin{array}{l}0.069 \\
(2.47)\end{array}$ & $\begin{array}{l}0.018 \\
(0.73)\end{array}$ & n.a. \\
\hline $\begin{array}{l}\text { Influenza, } \\
\text { Bronchitis, and } \\
\text { Pneumonia }\end{array}$ & $\begin{array}{l}\text { OSD Effect } \\
\text { t-statistic }\end{array}$ & $\begin{array}{l}-0.260 \\
(-8.62)\end{array}$ & $\begin{array}{l}-0.072 \\
(-2.08)\end{array}$ & $\begin{array}{l}-0.134 \\
(-3.06)\end{array}$ & $\begin{array}{l}0.321 \\
(1.26)\end{array}$ \\
\hline Diarrheal & $\begin{array}{l}\text { OSD Effect } \\
\text { t-statistic }\end{array}$ & $\begin{array}{r}-0.317 \\
(-12.66)\end{array}$ & $\begin{array}{l}-0.067 \\
(-2.48)\end{array}$ & $\begin{array}{r}-0.085 \\
(-2.6)\end{array}$ & $\begin{array}{l}-0.383 \\
(-1.91)\end{array}$ \\
\hline Degenerative & $\begin{array}{l}\text { OSD Effect } \\
\text { t-statistic }\end{array}$ & $\begin{array}{l}-0.079 \\
(-2.69)\end{array}$ & $\begin{array}{r}-0.137 \\
(-3.9)\end{array}$ & $\begin{array}{l}-0.075 \\
(-2.07)\end{array}$ & $\begin{array}{l}0.216 \\
(1.15)\end{array}$ \\
\hline Maternal Mortality & $\begin{array}{l}\text { OSD Effect } \\
\text { t-statistic }\end{array}$ & $\begin{array}{r}-0.350 \\
(-12.85)\end{array}$ & $\begin{array}{l}-0.051 \\
(-1.49)\end{array}$ & $\begin{array}{l}-0.010 \\
(-0.19)\end{array}$ & $\begin{array}{l}-0.058 \\
(-0.17)\end{array}$ \\
\hline Motor Vehicles & $\begin{array}{l}\text { OSD Effect } \\
\text { t-statistic }\end{array}$ & $\begin{array}{r}-0.151 \\
(-5.2)\end{array}$ & $\begin{array}{l}-0.042 \\
(-1.15)\end{array}$ & $\begin{array}{l}-0.214 \\
(-3.62)\end{array}$ & $\begin{array}{l}0.191 \\
(0.61)\end{array}$ \\
\hline $\begin{array}{l}\text { General Fertility } \\
\text { Rate }\end{array}$ & $\begin{array}{l}\text { OSD Effect } \\
\text { t-statistic }\end{array}$ & $\begin{array}{l}-0.169 \\
(-5.51)\end{array}$ & $\begin{array}{l}-0.307 \\
(-9.82)\end{array}$ & $\begin{array}{l}0.026 \\
(0.98)\end{array}$ & $\begin{array}{l}0.820 \\
(2.59)\end{array}$ \\
\hline $\begin{array}{l}\text { General Fertility } \\
\text { Rate controlling }\end{array}$ & $\begin{array}{l}\text { OSD Effect } \\
\text { t-statistic }\end{array}$ & $\begin{array}{r}-0.018 \\
(-0.52)\end{array}$ & $\begin{array}{r}-0.243 \\
(-8.02)\end{array}$ & $\begin{array}{r}0.019 \\
(0.72)\end{array}$ & $\begin{array}{l}0.877 \\
(2.78)\end{array}$ \\
\hline
\end{tabular}

Notes. The t-statistics are based on White-corrected robust standard errors. Correlates included in the death rate analyses are retail sales per capita, percent black, percent illiterate, percent urban, percent 
foreign-born, percentages of population in the age groupings 10-19, 20-29, 30-34, 35-44, 45-54, 55-64, 6574,75 and over. The identifying instruments are the swing measure, democratic governor, and house labor committee.

In the non-infant death rate analysis there are 1349 observations covering the period 1929-1940. The F-statistic on the instruments in the first stage for the noninfant death rate is 12.73 and the Hausman Chi-square test suggests that the instruments have not been inappropriately omitted. In the subsample with controls for the 1921-1928 trend, the results are similar between the estimates with and without the controls for trends. In some specifications the t-statistic for the swing measure was statistically insignificant in the first stage. When we remove it from the instrument list, the results are very similar to what is reported here and the F-statistic on the instruments in the first stage rises to 19.03. In the analysis of the non-infant death rate including controls for the general fertility rate and the infant mortality rate, the instruments were the swing and house labor committee measures and the F-statistic on the instruments in the first-stage was 5.66.

In the specific cause of death regressions the sample there are 1027 observations for the period 1929-1937 for all but the maternal mortality, for which there were 1007. The difference arises because in the sources the Texas cities reported causes of death but not births, which are the denominator in the maternal mortality rates. The instruments in the first stage were the swing measure, House labor committee, and democratic governor and the F-statistic for the grouping in the first stage was 8.03. For all causes except the cardiovascular diseases, the Hausman Chi-square tests suggests that the instruments have not been inappropriately omitted. In some specifications the t-statistic for the swing measure was statistically insignificant in the first stage. When we remove it from the instrument list, the results are very similar to what is reported here and the F-statistic on the instruments in the first stage rises to 12 . However, we start to have problems with some causes where the instruments appear to be inappropriately omitted. This occurs for suicides, respiratory tuberculosis, and cardiovascular deaths. The death rates for the death causes are scaled per 100,000 people, while the maternal mortality rate is scaled per 1000 live births.

In the general fertility analysis there are 1349 observations. Correlates included in the general fertility rate analyses are the same as in the infant mortality analysis in Table 3. The identifying instruments are the swing measure and the house labor committee. The F-statistics for the two identifiers are 11.58 and 11.41, and Hausman overidentification tests suggest that they have not been inappropriately excluded from the final stage equation. We excluded the Democratic governor variable because whenever it was included we rejected the hypothesis that the identifiers were not inappropriately excluded. 
Table 5

OSD Effects of Retail Sales per Capita on Demographic Variables

\begin{tabular}{|c|c|c|c|c|}
\hline & OLS Fix & Effects & \multicolumn{2}{|c|}{$\begin{array}{c}\text { 2SLS with Fixed } \\
\text { Effects }\end{array}$} \\
\hline & $\begin{array}{l}\text { OSD } \\
\text { Effect }\end{array}$ & t-stat.* & $\begin{array}{c}\text { OSD } \\
\text { Effect }\end{array}$ & t-stat.* \\
\hline Infant Mortality & 0.022 & 0.520 & -0.003 & -0.06 \\
\hline Noninfant Deaths & 0.068 & 1.910 & 0.061 & 1.66 \\
\hline Homicides & 0.171 & 3.960 & 0.154 & 3.52 \\
\hline Suicides & -0.168 & -1.980 & -0.235 & -2.55 \\
\hline $\begin{array}{l}\text { Respiratory Tuberculosis } \\
\text { Infectious and Parasitic }\end{array}$ & 0.063 & 1.570 & 0.076 & 1.74 \\
\hline Diseases & 0.216 & 2.740 & 0.152 & 1.77 \\
\hline Neoplasms & 0.102 & 1.510 & 0.122 & 2.02 \\
\hline $\begin{array}{l}\text { Cardiovascular Disease } \\
\text { Influenza, Bronchitis, and }\end{array}$ & 0.004 & 0.110 & 0.042 & 0.9 \\
\hline Pneumonia & -0.128 & -1.970 & -0.087 & -1.23 \\
\hline Diarrheal & 0.010 & 0.210 & -0.017 & -0.32 \\
\hline Degenerative & 0.133 & 2.690 & 0.160 & 3 \\
\hline Maternal Mortality & 0.150 & 1.620 & 0.145 & 1.5 \\
\hline Motor Vehicles & 0.252 & 3.030 & 0.289 & 3.18 \\
\hline General Fertility Rate & 0.357 & 6.970 & 0.410 & 6.63 \\
\hline
\end{tabular}

Notes. The OSD effect is the number of standard deviations by which the infant mortality rate is changed when retail sales per capita rose by one standard deviation. The t-statistics are based on White-corrected robust standard errors. The OSD estimates are based on coefficients of retail sales per capita for each demographic variable in the estimations with all correlates and fixed effects from the equations that produced the relief spending effects. 2SLS refers to the use of instruments for the relief per capita variable. The t-statistics are for the original coefficients. 
Table 6

\section{Relief Cost per Death Prevented in Year 2000 Dollars}

\author{
Infant Mortality \\ Non-infant Death \\ Homicide \\ Suicide \\ Death from Infectious and \\ Parasitic Disease \\ Deaths from Diarrhea
}

$\begin{array}{cc}\begin{array}{c}\text { Estimate Based on Coefficient from } \\ \text { Specification }\end{array} \\ \begin{array}{c}\text { OLS with } \\ \text { Correlates and }\end{array} & \text { 2SLS with Fixed } \\ \text { Fixed Effects } & \text { Effects } \\ \$ 8,614,412 & \$ 1,947,976 \\ \$ 2,482,176 & \$ 659,819 \\ \$ 29,714,799 & \$ 4,547,812 \\ \$ 13,389,218 & \$ 1,935,784 \\ & \\ \text { n.a. } & \$ 840,014 \\ \$ 7,944,865 & \$ 1,760,966\end{array}$

Notes. Values for all but the 2SLS estimate for Non-infant deaths are statistically significant at the 20 percent level in two-tailed tests. See Tables 2 and 4 for the t-statistics for the coefficients on which the estimates are based. The estimates are based on coefficients from specifications that include correlates and fixed effects. See text and footnotes for methods of calculation. The relief costs are insensitive to changes in the population size. The relief costs for infant deaths are sensitive to changes in the ratio of women aged 15 to 44 to the population and the general fertility rate. The coefficients were estimated with monetary values based on the CPI with 1967 as the base year. Dollar values were converted to 2000 values by multiplying by 5.213. The 2000 values can be converted to 1935 values by dividing by 12.68 . 
Figure 1

Infant Mortality and General Fertility Rates, 1915-1940 and Trend Based on 1915-1917, 1919-1929

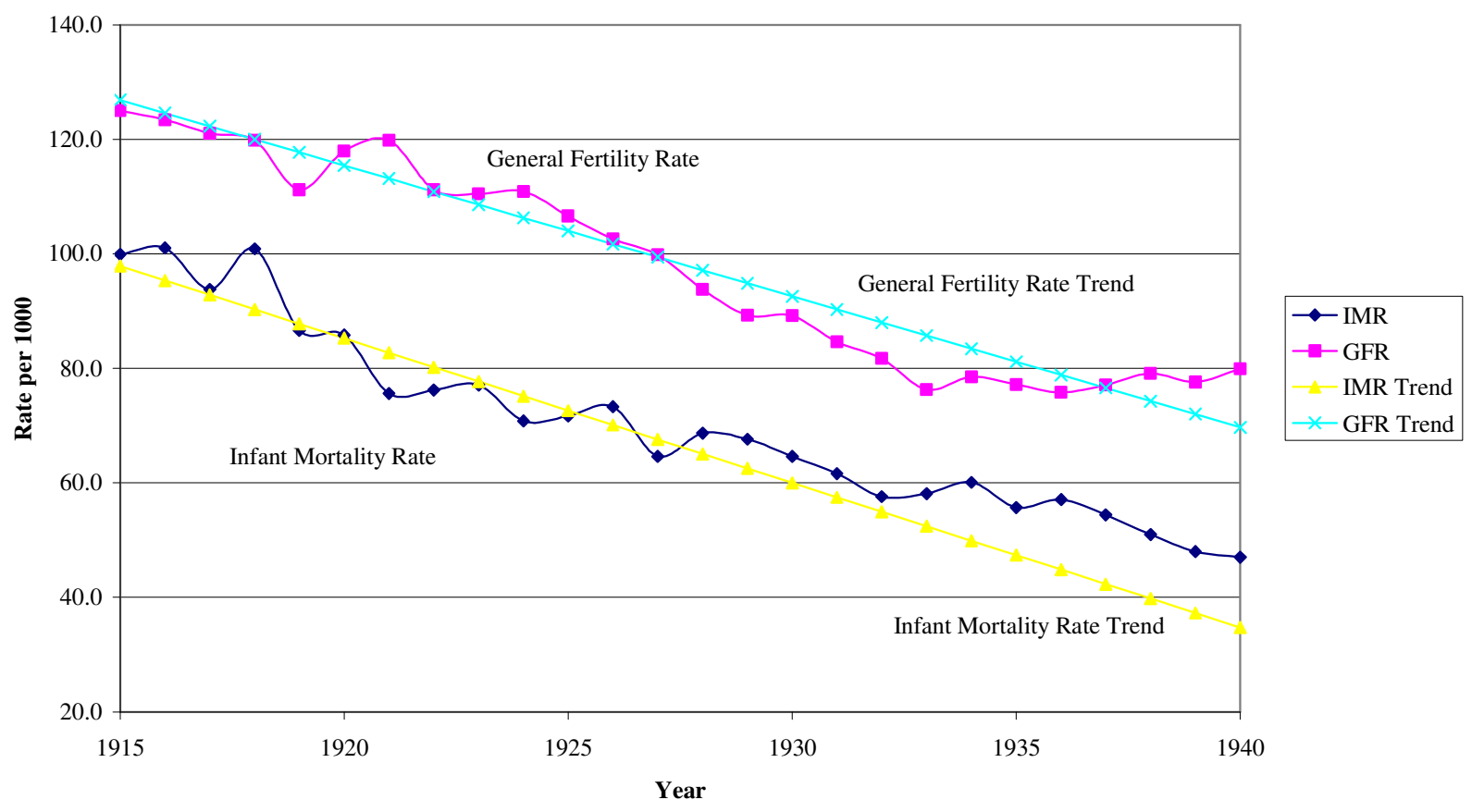


Figure 2

Non-Infant Death Rate 1915-1940 and Trend based on 1915-1917, 1919-1929

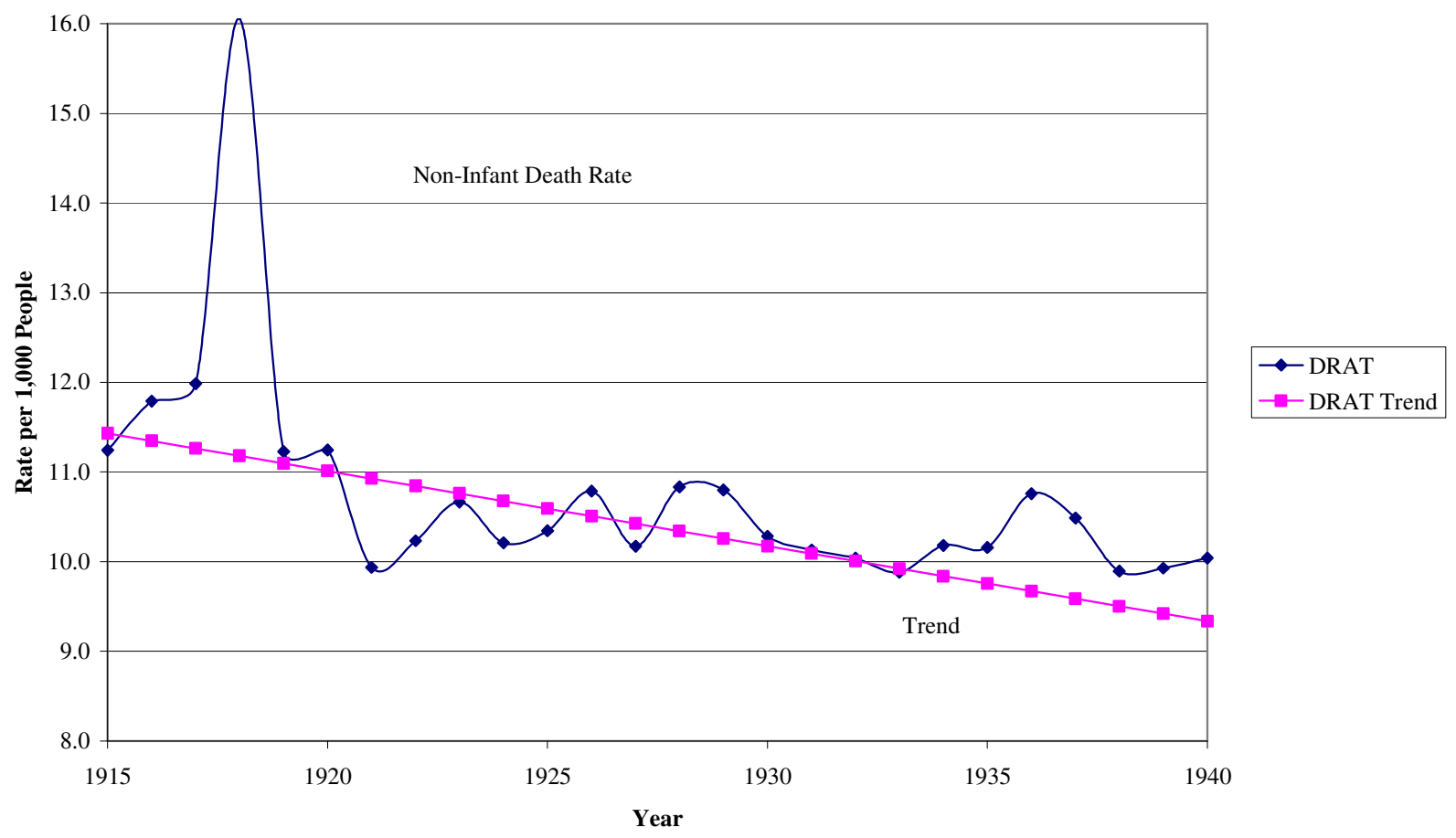


Figure 3

Plot of Differences in Differences

Between 1930-32 and 1933-1940 for Sample Cities

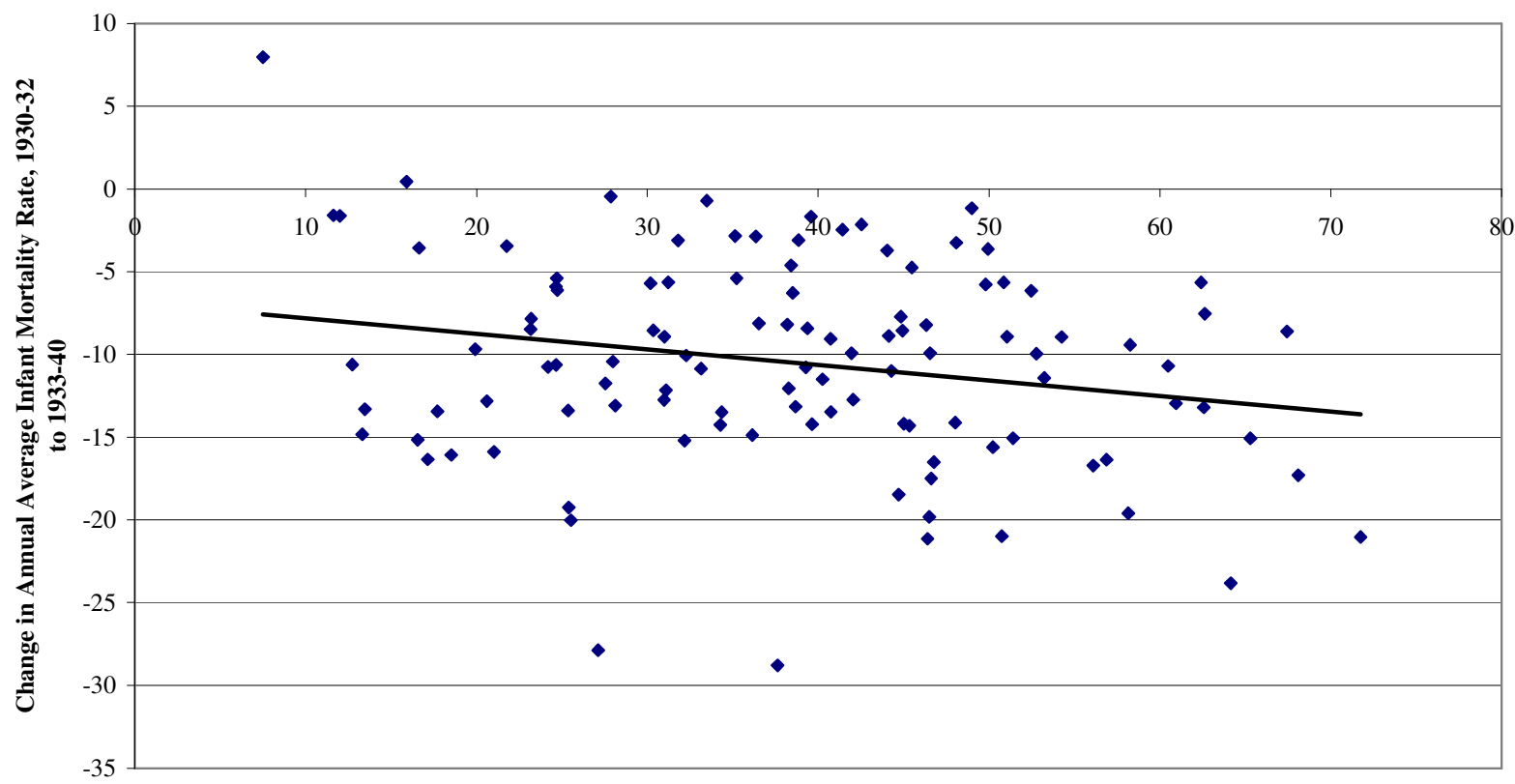

Change in Annual Average Relief per Capita, 1930-32 to 1933-40 